\title{
The Quaternary plant fossil record from the volcanic Azores Archipelago (Portugal, North Atlantic Ocean): a review
}

Carlos A. Góis-Marques, Lea de Nascimento, Miguel Menezes de Sequeira, José María Fernández-Palacios \& José Madeira

To cite this article: Carlos A. Góis-Marques, Lea de Nascimento, Miguel Menezes de Sequeira, José María Fernández-Palacios \& José Madeira (2018): The Quaternary plant fossil record from the volcanic Azores Archipelago (Portugal, North Atlantic Ocean): a review, Historical Biology, DOI: 10.1080/08912963.2018.1444761

To link to this article: https://doi.org/10.1080/08912963.2018.1444761

曲 Published online: 28 Feb 2018.

Submit your article to this journal $₫$

Q View related articles $\sqsubset$

View Crossmark data ¿ 


\title{
The Quaternary plant fossil record from the volcanic Azores Archipelago (Portugal, North Atlantic Ocean): a review
}

\author{
Carlos A. Góis-Marques ${ }^{a, b}$ (D), Lea de Nascimentoc (D), Miguel Menezes de Sequeirab,d (D), \\ José María Fernández-Palaciosc (iD) and José Madeira ${ }^{a}$ (iD)
}

aLaboratório Associado, Departamento de Geologia, Faculdade de Ciências da Universidade de Lisboa and Instituto Dom Luiz (IDL), Universidade de Lisboa, Lisboa, Portugal; bFaculdade de Ciências da Vida, Madeira Botanical Group (GBM), Universidade da Madeira, Funchal, Portugal; ' Island Ecology and Biogeography Group, Instituto Universitario de Enfermedades Tropicales y Salud Pública de Canarias (IUETSPC), Universidad de La Laguna (ULL), La Laguna, Spain; ${ }^{\mathrm{d}} \mathrm{CIBIO}$ Centro de Investigação em Biodiversidade e Recursos Genéticos, InBIO Laboratório Associado, Pólo dos Açores, Portugal

\begin{abstract}
Plant fossils are known from the Azores Islands, yet poorly studied. We present a comprehensive bibliographical review for the archipelago. A first pre-scientific reference dates from late fifteenth century, while the first scientific description was reported in 1821, accounting for trunks in pyroclastic units and silicified plants within hydrothermal deposits. Throughout the second-half of the nineteenth century and the first-half of the twentieth century, prospection by naturalists and geological mapping work, led to the discovery and description of plant fossils in most islands. From the 1970s onwards, the taxonomic interest ceased, and plant fossils were used mainly for ${ }^{14} \mathrm{C}$ dating. Recently, sediment cores from lakes and peatlands were used for palaeoecological reconstructions and to measure anthropogenic impacts. Generally, plant fossils are younger than $50 \mathrm{ka}$, although older fossils may exist. Azorean plant fossils include somatofossils of leaves, stems, logs and seeds preserved as impressions, compressions, adpressions, permineralizations, lava tree casts and mummifications. The taphonomy of macrofloral elements is usually related to explosive volcanic activity, while palynological record is associated with lake sediments and peat bogs. The persistence in palaeobotanical and palaeopalynological studies will decisively contribute to disentangle the paleodiversity, palaeoecology, and add crucial information on insular plant phylogeny and biogeography.
\end{abstract}

ARTICLE HISTORY

Received 23 December 2017 Accepted 20 February 2018

\section{KEYWORDS}

Macaronesia; Azores Islands; history of palaeontology; plant fossils; taphonomy; palaeoecology

\section{Introduction}

Oceanic islands are considered exceptional natural biological laboratories due to their potential for the observation and study of evolution, ecology and biogeography in a discrete area (e.g. Whittaker and Fernández-Palacios 2007). Indissociable from the islands' biological component, their geologic history is paramount in shaping life evolution, as proposed by the general dynamic theory of oceanic island biogeography (Whittaker et al. 2008; Triantis et al. 2016; Borregaard et al. 2017). Predictably, island ontogeny also promotes the interaction of the geological and biological components, implying ultimately, that oceanic island biotas are exposed to taphonomical processes that can lead to their preservation as fossils.

Geological observations in the Azores Islands, especially due to their active tectonics and volcanism, secondary volcanic manifestations, and geomorphological aspects, resulted in several publications throughout the nineteenth century (e.g. Webster 1821; Boid 1834; Hartung 1860; Fouqué 1873a, 1873b, 1873c). These publications reported the existence of plant fossils, specially buried tree trunks entombed in pyroclastic layers, some of large dimensions (e.g. Webster 1821; Boid 1834). These macrofossils reports were usually used as proof of the existence of a palaeovegetation composed of large trees, contrasting with the anthropically modified landscape that these naturalists observed (Webster 1821; Fouqué 1873b; Guppy 1917; Borges 2007). The presence of forests composed of trees of great dimension is corroborated by the old Portuguese chronicles (e.g. Fernandes 1508; Frutuoso 1590a, 1590b). They describe that several Azorean islands were covered by primeval forests formed by large evergreen broadleaved trees and conifers. The Portuguese colonization of the islands, ca. 1432, resulted in the exploitation of the native forests for local use and exportation to mainland Portugal (Guppy 1917; Dias 2007). Frutuoso's narrative, describing the initial 150 years of colonization, already mentions an intense agricultural, livestock and forestry exploitation in São Miguel Island, which resulted even then, in the necessity to control logging (Frutuoso 1590a; Dias 2007). Moreover, the first descriptions of the floras of the Azores archipelago were only published more than 400 years after the beginning of the settlement (e.g. Seubert 1844; Trelease 1897), although description of endemic plants were published by late eighteenth century (Aiton 1789). It is calculated that >95\% of Azorean natural vegetation was devastated throughout the 
almost 600 years of colonization (Triantis et al. 2010). Reported examples of plant extirpations (local extinctions) in the Azores are scarce but known from some islands (e.g. Juniperus brevifolia and Prunus lusitanica from Santa Maria Island; Taxus baccata in São Miguel, Dias 2007; Ophioglossum azoricum and O. lusitanicum, Connor et al. 2012). Reports of plant extinctions, such as Vicia dennesiana H. C. Watson in São Miguel (Palhinha 1966; Franco 1971) are rare, possibly due to pre-scientific extinctions (Jardim and Menezes de Sequeira 2008).

In recent years, an interest in the terrestrial palaeoecology of the archipelago, especially for the Holocene, has emerged. It aims at describing long-term changes in palaeovegetation and to measure the anthropic impacts in these insular ecosystems, through the study of lake sediment cores using multi-proxy methods, like pollen and charcoal analysis (van Leeuwen et al. 2005; Connor et al. 2012, 2013; Rull et al. 2017b). However, previous works published during the 19th and 20th centuries containing palaeobotanical observations and descriptions are seldom cited. Moreover, insular vegetation studies do not cite the presence of a plant fossil record in these islands (e.g. Dias et al. 2005; Elias et al. 2016; and references therein). This is due to the lack of palaeobotanical studies and to the dispersion of the relevant bibliography through distinct fields of knowledge such as geology and botany, and the linguistic barrier, since those reports are written in 4 different languages (i.e. English, French, Portuguese and German), making the pertinent bibliography difficult to summarise and cite. Moreover, a state of art of the palaeobotany and palynology from the Azores Arquipelago has never been performed despite some attempts to summarize the macrofossil record found in some islands (e.g. Guppy 1917; Teixeira and Pais 1976; Anderson et al. 2009; Góis-Marques 2013; Góis-Marques and Menezes de Sequeira 2015), but without a formal revision or contextualization of these remains.

This paper aims at presenting the state-of-art of the palaeobotanical and palaeopalynological record of the vascular plants (i.e. Pteridophyta and Spermatophyta) from the Azores archipelago.
Here, we make an historical review for all Azorean Islands with a discussion of the taxonomy and nomenclature, taphonomy, preservation and age of the published plant fossils, and present future perspectives on how the palaeobotanical and palaeopalynological studies can contribute to understand the flora and vegetation of these oceanic islands.

\section{Geological setting}

The Azores archipelago is located in the central North Atlantic Ocean, lying across the triple junction between the North American, Eurasian and Nubian lithospheric plates (Figure 1(A)). This complex geotectonic setting coupled with a volcanic hot spot is proposed to explain the volcanism that produced the Azores islands (Gente et al. 2003). The archipelago is composed of nine islands geographically divided into three groups, the western group (Figure 1(B)): Corvo $\left(17.1 \mathrm{~km}^{2}\right.$, maximum elevation $720 \mathrm{~m}$ above sea level [a.s.l.]) and Flores (143 $\mathrm{km}^{2}$; $915 \mathrm{~m}$ a.s.l.); the central group: Faial $\left(170 \mathrm{~km}^{2} ; 1043 \mathrm{~m}\right.$ a.s.l.), Pico $\left(448 \mathrm{~km}^{2}\right.$; $2351 \mathrm{~m}$ a.s.l.), São Jorge ( $246 \mathrm{~km}^{2} ; 1.053 \mathrm{~m}$ a.s.l.), Terceira (400 $\mathrm{km}^{2} ; 1.021 \mathrm{~m}$ a.s.l.) and Graciosa (61.6 km²; $402 \mathrm{~m}$ a.s.l.); and the eastern group: São Miguel $\left(742 \mathrm{~km}^{2} ; 874 \mathrm{~m}\right.$ a.s.l. $)$ and Santa Maria $\left(97 \mathrm{~km}^{2} ; 587 \mathrm{~m}\right.$ a.s.l.).

The geology of the islands is summarized in Pacheco et al. (2013), while in the last ten years several papers describing or reviewing the structure and evolution of individual islands were published (e.g. Hildenbrand et al. 2008, 2012; Sibrant et al. 2015; Ramalho et al. 2017). The volcanism in Azores is related to basaltic magmas (s.l.), producing hawaiian, strombolian and surtseyan eruptions associated to fissural volcanism, and trachytic magmas that produced explosive phreatomagmatic and sub-plinian magmatic eruptions at central volcanoes, the latter being an important taphonomical agent, as it will be discussed later in this paper. Also, important for island biological colonization and evolution is the emergence ages of each island. In the Azores, the oldest island is Santa Maria having emerged $\sim 6$ My ago, but presenting

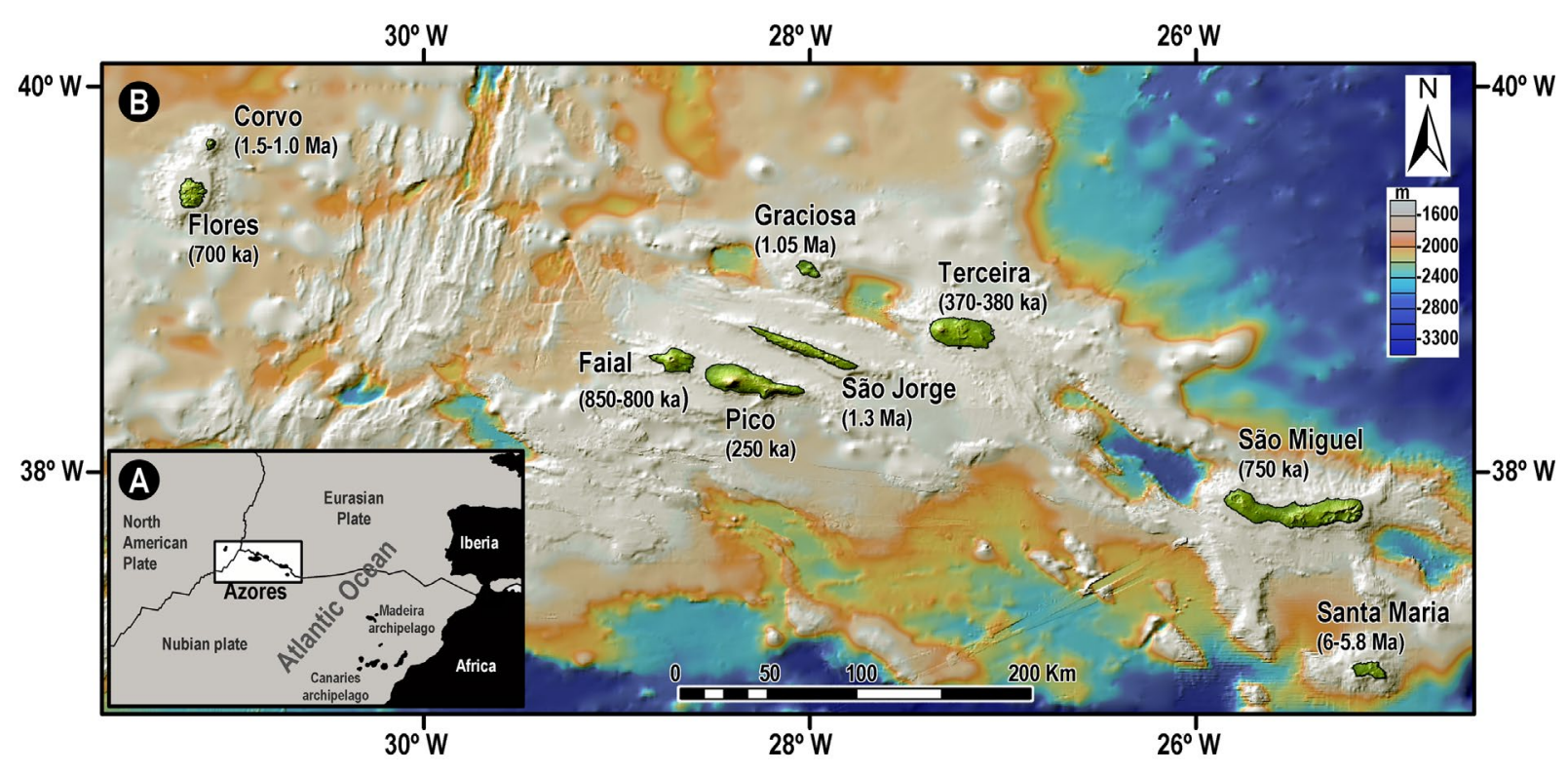

Figure 1. Geological setting of the Azores Archipelago. (A) location and tectonic setting; (B) detail of the Azores Archipelago bathymetry and oldest subaerial ages for each island.

Note: Digital elevation models generated in GeoMapapp (http://www.geomapapp.org) using the global multi-resolution topography (Ryan et al. 2009). 
a complex history of subsidence and erosion, growth by renewed volcanism followed by important uplift (Ramalho et al. 2017); in São Miguel the oldest subaerial volcanism corresponds to the <1 My old Nordeste volcano (Johnson et al. 1998; Sibrant et al. 2015 and references therein), infirming previous published ages of 4.01 Ma (Abdel-Monem et al. 1975); Terceira's oldest subaerial volcanism dates back to 370-388 ky (Calvert et al. 2006); Faial emerged at 850-800 ky ago (Hildenbrand et al. 2012); Pico is $250 \pm 40 \mathrm{ky}$ old (Demande et al. 1982 in Costa et al. 2015); São Jorge emerged at around 1.3 Ma (Hildenbrand et al. 2008); Graciosa is dated at $1.05 \mathrm{Ma}$ (Larrea et al. 2014); Flores subaerial phase is dated at $700 \mathrm{ka}$ (Azevedo and Portugal Ferreira 2006); Corvo is around 1.5-1.0 Ma old (França et al. 2006). The archipelago is volcanically active with at least 27 historical eruptions recorded since settlement (Madeira 2005). The latest subaerial volcanic manifestation occurred in 1957-1958 in Faial Island during the final phases of the initially submarine Capelinhos eruption (Zbyszewski, Moitinho d'Almeida, et al. 1959).

\section{Methodology}

A synthesis of the palaeobotanical and palaeopalynological knowledge from Azores archipelago was achieved through a bibliographic review, taking as starting points the palaeobotanical available summaries (Guppy 1917; Teixeira and Pais 1976; Anderson et al. 2009; Góis-Marques 2013; Góis-Marques and Menezes de Sequeira 2015). The review focused in books, papers, reports and letters (e.g. Arruda 2002) that could present direct studies (e.g. field observations, taxonomic studies) or indirect (e.g. fossils used as radiocarbon dating material), or mentions to the occurrence of plant fossils. The results were compiled and organized for the archipelago, and chronologically for each island. To corroborate and test the presence of plant fossils in these islands, field prospections were carried out in Terceira and Faial Islands in July 2016, and a visit was made to the collections held at the 'Museu Vulcanoespeleológico - Os Montanheiros'. Plant nomenclature and systematics follows Menezes de Sequeira et al. (2012). Described fossil taxa with old nomenclature were revised and accepted names given in brackets. Wood remains that suffered pyrolysis in the absence of oxygen due to high temperature pyroclastic flows are described as charcoalifications, following the proposal by Scott (2010). The term adpression is used sensu Shute and Cleal (1987), describing a specimen presenting a combination of compression and impression.

\section{Results: palaeobotany and palaeopalynology of Azores Archipelago}

The bibliographical research revealed 97 direct and indirect palaeobotanical or paleopalynological references, summing up to 107 mentions, as some publications deal with more than one island. The count of citations per island, from east to west, is as follows: Santa Maria: 1; São Miguel: 57; Terceira: 14; São Jorge: 3; Pico: 8; Faial: 14; Graciosa: 4; Flores: 5; and Corvo: 1.

The analysis of the number of publications per decade, allows discriminating seven historical phases (Figure 2). The 1st phase (one publication found), corresponds to the pre-scientific description of the first palaeobotanical record by Frutuoso (1590b), with the reference to buried trunks of Taxus baccata in Pico Island (see section about Pico Island). The 2 nd phase (12 publications found), extends from 1821 up to the 1860's, with the discovery and first scientific descriptions of charcoalified and mummified wood in tephra deposits and silicified plants (Webster 1821; Boid 1834). The 3rd phase (12 publications found), spans the 1860s-1880s period, with the discovery of lignite and leaf fossils (Hartung 1860), and later, the discovery of leaf fossils by the Azorean naturalist Arruda Furtado, following indications from Darwin to Hooker (Arruda 2002; Góis-Marques and Menezes de Sequeira 2015). The 4 th phase (15 publications found), extends from the last two decades of the nineteenth century to the first half of the twentieth century, with publications about the discovery, or citations of, plant macrofossils (e.g. Canto e Castro 1890; Dionísio 1937; Berthois 1948; Agostinho 1949). The 5th phase (seven publications found) covers the 1960's-1970's period, where the surveys to produce geological maps of some islands lead to the discovery of several fossil beds and the illustration of the first leaf fossils (e.g. Zbyszewski, Moitinho d'Almeida, et al. 1959; Zbyszewski et al. 1971; Forjaz 1960). The 6th phase (21 publications found) corresponds to the last 2 decades of the twentieth century to the present, coinciding with the increasing use of radiocarbon dating using charcoalified and mummified plants, but whose taxonomy was ignored (e.g. Fries 1968; Shotton et al. 1974; Booth et al. 1978; Moore and Rubin 1991; Madeira et al. 1995, 1998; Nunes 1999; Pacheco 2001; Gertisser et al. 2010; Pacheco 2015; Calvert et al. 2006). Finally, the present 7 th phase (29 publications found), with the raising interest in palynomorphs from lake and bog sediment cores to describe the palaeoecological and anthropogenic impacts during the Holocene in several islands (Connor et al. 2012, 2013; Rull et al. 2017b).

Individually, each island presents a different history, depending on the number of geological and botanical explorations, and its geology. In the following sections, a brief commented historical perspective for each island, from east to west, is presented.

\section{Santa Maria Island}

The only plant fossil reference for Santa Maria Island is found in Anderson (2009, Appendix S1), citing Amen (2002). This work reports the presence of rhizoliths associated with beach sediments at Prainha (see Figure 3(B)). However, while the stratigraphy and palaeontology of Prainha outcrop was studied in detail due to the presence of Pleistocene marine fossils, no rhizoliths were described for that section (e.g. Ávila et al. 2009, 2010). As an additional note, rhodoliths (Rhodophyta) were described from the sedimentary beds of Santa Maria Island (see Rebelo et al. 2016 and references therein).

\section{São Miguel Island}

For São Miguel Island, a total of 57 references were found, describing or citing palaeobotanical and palynological occurrences distributed throughout the island with the exception of the eastern part (Figure 3(B)). The first reference is given by Webster (1821), mentioning mummified and charcoalified tree trunks around Sete Cidades Caldeira (Webster 1821, p. 161). In Furnas valley, he describes charcoalified trunks buried in a pumice layer exposed in a road cut, some still in vertical position: 


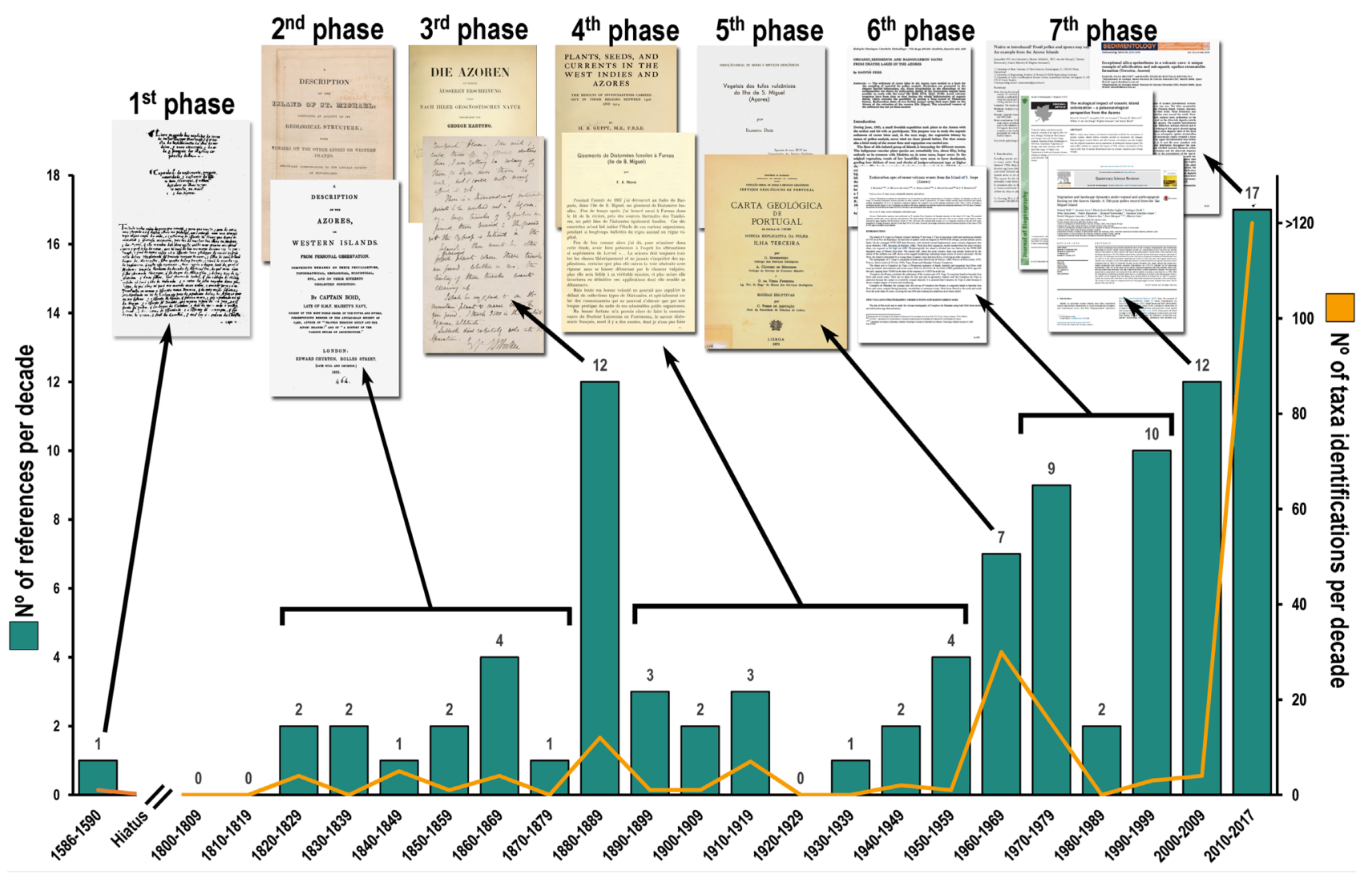

Figure 2. Palaeobotanical and palynological publications per decade and taxa identifications/references for the Azores Islands. From left to right: 1st phase, pre-scientific and first account on the palaeobotany of Azores by Frutuoso (1590a); 2nd phase, first scientific accounts (e.g. Webster 1821; Boid 1834); 3rd phase, palaeobotanical discoveries by Arruda Furtado incited by Darwin and Hooker (Hartung 1860; Arruda 2002), showing a small spike in taxa description; 4th phase, reports or citations from late nineteenth century to late 1950's (e.g. Chaves 1908; Guppy 1917); 5th phase discovery of macrofossils in several islands and first illustrations, with a spike in taxa mention (e.g. Diniz 1962; Zbyszewski et al. 1971); 6th phase, use of plant macrofossils for ${ }^{14} \mathrm{C}$ dating (e.g. Fries 1968; Madeira et al. 1998); 7th phase, new interest in Azores palaeoecology, when more than 100 types of palynomorphs are identified in sedimentary cores (e.g. van Leeuwen et al. 2005; Connor et al. 2012; Rull et al. 2017b).

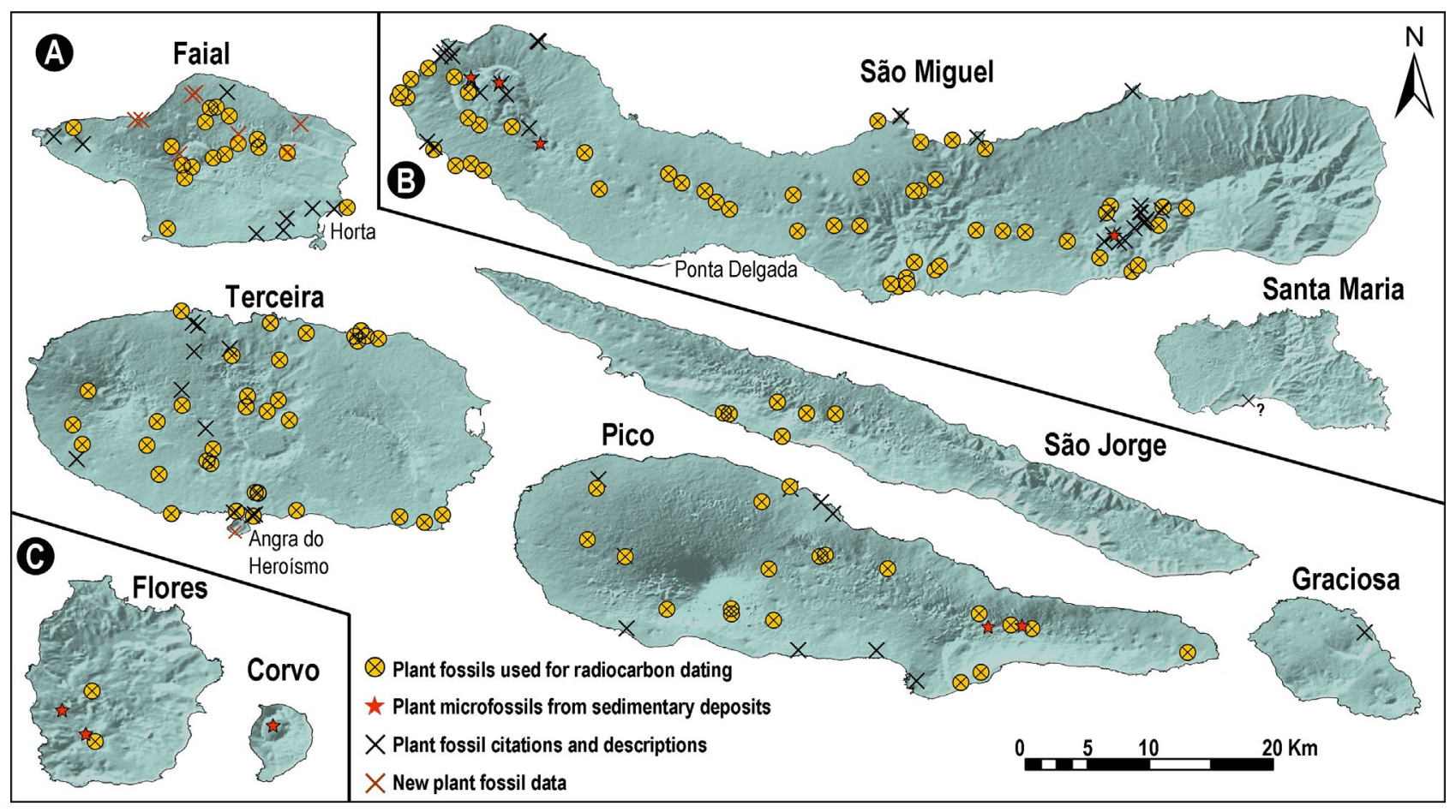

Figure 3. Location of sites of palaeobotanical interest reported in the bibliography and from field observations in the nine islands of the Azores. (A) Central group; (B) Eastern group; (C) Western group.

Notes: Digital elevation models generated in GeoMapapp (http://www.geomapapp.org) using the global multi-resolution topography (Ryan et al. 2009). 
... considerable quantities of bituminous wood were discovered, partly in the pumice (...) in a horizontal direction. In some places, distinct trunks of trees, of a diameter far exceeding that of the present growth of wood upon the island, were observed (...); many of them rise through the pumice in a natural position (...). (Webster 1821, p. 199)

Furthermore, he describes the silicification of plants remains in the hot springs of Furnas Caldera: 'Vegetables, grass, leaves, and similar substances which have been exposed to the influence of the water, are ... incrusted with silex, and exhibit all the progressive steps of petrifaction ...' (Webster 1821, p. 209). He also mentions silicified ferns and a fossil bed of silicified reeds (Juncaceae? Cyperaceae?): 'I found branches of ferns which now flourish on the island, completely petrified, preserving every appearance as when vegetating, excepting the colour, which is now ash grey. Fragments of wood, (...), and one entire bed, from three to five feet in depth, is composed of the reeds so common on the island, completely mineralized' (Webster 1821, p. 209). The last description found in Webster (1821) refers to cedar (probably Juniperus brevifolia) and beech (probably Morella faya) trunks, in the locality of Ponta da Ajuda (Webster 1821, p. 218).

The next reference is given by Mouzinho de Albuquerque and Menezes (1826) reporting the observation of charcoalified trunks in Furnas. De La Beche (1832) cites Webster (1821) about the discovery of silicified plants and unaltered trunks in tephra deposits. Hunt (1845a, 1845b) publishes two papers dealing with the geology of São Miguel and Santa Maria, where the presence of plant macrofossils associated to a palaeosol baked by a basaltic lava flow, in the west part of São Miguel is described: 'The heat of the succeeding streams of fluid lava has converted their upper surfaces into a red ochrey substance, when the roots and other remains of ferns and associated plants of the time are now found in the state of a scarcely coherent charcoal' (Hunt 1845b, p. 273). The same author also cites the presence of 'Myrica, cedar, myrtle and Erica arborea ... being easily recognised in their state of lignite' (Hunt 1845b, p. 259), although not citing the fossil locality, but most probably mentioning examples observed in São Miguel Island.

Conybeare (1851), visited São Miguel in 1849 (North 1933), publishing a small geological note describing the presence of charcoalified tree trunks in Furnas valley and mummified trunks in the North slope of Furnas Caldera, stating that some of the wood was locally used in woodworks (Conybeare 1851, p. 45). Drouet (1857) describes the frequent discovery of buried trunks in São Miguel, most probably citing the previous mentions for São Miguel (Drouët 1851, p. 29).

Later, Hartung (1860) published an important book about the geology of the Azores Archipelago, summarizing geological observations made in 1857 (Pinto and Bouheiry 2007). Palaeontological contribution deals mostly with the marine fossils from Santa Maria. However, he also mentions the presence of Juniperus cedrus (= J. brevifolia) trunks buried in Furnas Caldera in São Miguel (Hartung 1860, p. 200), and in a footnote, the discovery of two thin lignite levels associated with leaf impressions that were found by W. Reiss at the base of Pico de Ferro, in Furnas (see Hartung 1860, p. 151). Drouet (1866) describes the discovery of a huge Juniperus oxycedrus (= J. brevifolia) half charcoalified trunk in Furnas.

The next publication is by Goeze (1867b, 1867a). This author compares the mummified wood dug under $100 \mathrm{~m}$ of tephra in
São Miguel (unknown locality), with the wood of Cupressus glauca (= Cupressus lusitanica). This author supposed that $C$. glauca could have been native in Azores. Goeze (1867a) states that he sent samples to Kew Gardens (UK) for identification. A search in the Kew Economic Botany Collection (http://apps.kew. org/ecbot/search) provides further evidence that the specimen sent by Goeze was identified as Juniperus sp., most probably is $J$. brevifolia. (see Catalogue Number: 25097).

In 1873, Fouqué in a series of three articles about the geology of Azores islands (Fouqué 1873a, 1873b, 1873c), describes the presence of buried trunks in pyroclastic deposits in Sete Cidades (Fouqué 1873c, p. 841) and refers to Hartung (1860) for the presence of lignite in Furnas. Chronologically, the next documents are the correspondence between Arruda Furtado, Charles Darwin and Joseph Dalton Hooker and later with W.T. Thyselton-Dyer and Louis Compton Miall (Arruda 2002). According to the letters, a prospection for Cupressus sp. trunks was encouraged by Hooker in a letter written by Darwin to Arruda Furtado on the 12th of September of 1881 (Arruda 2002, p. 114; GóisMarques and Menezes de Sequeira 2015). The prospection of plant fossils by Arruda Furtado lead to the discovery of a leaf bed in Mosteiros, as reported on the 21st of November of 1881 (Arruda 2002, p. 117). In total, 11 letters citing Azorean plant fossils can be found in the correspondence of Arruda Furtado (12 September 1881 [Arruda 2002, p. 114]; 16 October 1881 [Arruda 2002, p. 145]; 16 October 1881 [Arruda 2002, p. 115]; 21 November 1881 [Arruda 2002, p. 117]; 19 December 1881 [Arruda 2002, p. 150], where leaf impressions are identified as Laurus canariensis (=L. azorica) and Notelaea excelsa (=Picconia azorica); 19 March 1882: [Arruda 2002, p. 152-153;; 5 April 1882 [Arruda 2002, p. 155]; unknown day May 1882 [Arruda 2002, p. 97]; 22 May 1882 [Arruda 2002, p. 99]; 29 June 1882 [Arruda 2002, p. 156]; 16 August. 1882 [Arruda 2002, p. 99]).

The next references are mainly citations of previous works: Walker (1886), writes about the presence in Sete Cidades and Furnas Valley slopes of mummified and charcoalified trunks. Canto e Castro (1890) in an essay about the geology of the Azores Archipelago cites Hartung (1860). Bensaúde (1892) mentions the occurrence of leaf impressions in Bretanha region (NW São Miguel), adding that this fossil flora was studied by Count Solms, and that he confirmed the presence of a distinct paleoflora. Trelease (1897) cites the presence of lignite and 'tufa casts of existing species of higher plants' (Trelease 1897, p. 78), and the presence of 'large logs' in Sete Cidades (Trelease 1897, p. 169); Kent (1900) mentions the presence of abundant tree trunk fossils of J. brevifolia. Chaves (1908) describes the attempt to locate the lignite levels described by Hartung (1860). However, he ends up finding two diatomite outcrops, leading to the description of two diatomaceous floras (the Tambores and Bargado fossil floras). Elwes and Henry (1910), mention the discovery of buried trunks previously identified as Cupressus sempervirens or C. lusitanica, that were studied in Kew Gardens, and identified as Juniperus cf. brevifolia. Most probably these were the results obtained from the specimens sent by Goeze (1867a, 1867b) to Kew Gardens.

Guppy $(1914,1917)$, in an attempt to prove that in the past, all the Azorean Islands were covered by large trees, summarizes the known publications about mummified or charcoalified trunks of large proportions found in the Archipelago, citing previous works (e.g. Hunt 1845a; Drouet 1857; Hartung 1860; Walker 
1886; Trelease 1897). Guppy (1917) also cites a letter from Afonso Chaves stating that the trunks discovered in São Miguel are not charcoalified (Guppy 1917, p. 394).

The following references mentioning plant fossils are published 42 years later in the explanatory notes of the geological maps of São Miguel (Zbyszewski et al. 1958; Zbyszewski, da Veiga Ferreira, et al. 1959). Plant macrofossils are described East of Monte Frescão (Zbyszewski et al. 1958), at Risco (Candelária), Mosteiros beach, Grota da Cova (Bretanha) and Ponta do Cintrão (Ribeirinha) (Zbyszewski, da Veiga Ferreira, et al. 1959, p. 11). Diniz (1962) published a taxonomic description of leaf impressions preserved in tuff from two localities, Eira Velha, (Mosteiros) and Risco da Candelária. It is worth mentioning that in Eira Velha, Diniz (1962) describes fern fronds in an upright position, most probably buried in situ. The two sites are described together, and 15 taxa identified: Filicopsida: Blechnum spicant (L.) Wither [=B. spicant (L.) Roth], Asplenium marinum L., Pteridium aquilinum (L.) Kuhn; Magnoliopsida: Smilax excelsa L. (probably S. canariensis Brouss. ex Willd.), Myrica faya Ait. [= Morella faya (Aiton) Wilbur], Daphne laureola L., Phytolacca americana L. (an alien plant, Menezes de Sequeira et al. 2012), Pittosporum undulatum Vent. (an alien plant, Silva et al. 2008), Hedera canariensis (H. azorica Carrière), Laurus azorica (Seub.) Franco, Ocotea foetens (Ait.) Baill (Figure 4(A), n 1-3), Ilex perado Ait (Figure 4(A), numbers 4-7)., Notelaea excelsa Webb [= Picconia azorica (Tutin) Knobl], Vaccinium cylindraceum Sm., Lonicera etrusca Santi, Viburnum tinus L. var. subcordatum (Trel.) P. Silva (= Viburnum treleasei Gand.). It is worth noticing that some of the identifications are from well-known alien plants (e.g. P. ondulatum, P. americana) in the island and archipelago, and that the possible identification of $O$. foetens could indicate an extirpation of a Lauraceae tree from the island and archipelago. These fossils are deposited at the Museu Geológico (Lisboa, Portugal), waiting for a revision.

The development of the radiocarbon dating method in the 1950s (Taylor 2016), led in the 1960s and 1970s to a new interest in plant fossils suitable for radiocarbon dating the volcanic events that entombed them. The first radiocarbon dates for São Miguel were reported by Fries (1968). This paper dealt with the possibility of coring lakes and lagoons from the Azores to obtain sediment cores in order to reconstruct the palaeovegetation through palynological analysis. In São Miguel, three sites were studied, the Lagoa Azul (oldest cored sediments yielded an age of $845 \pm 200$ years BP), Lagoa das Furnas (3930 \pm 200 years BP) and Lagoa Rasa ( $<250 \mathrm{yr}$ ). Other potential sites for palaeoecological studies were pointed out, such as Lagoa do Fogo, Lagoa Verde, Lagoa de São Tiago, Lagoa do Carvão, Lagoa de São Braz and Lagoa do Congro. Fries (1968), also reports three radiocarbon dates obtained from mummified Juniperus sp. trunks found buried in Sete Cidades caldera (Samples Az 1: $3435 \pm 75$ years BP and $4167 \pm 230$ years BP; sample Az2: $1815 \pm 65$ years BP).

The development of the volcano-stratigraphy of São Miguel island led to the discovery and mention of the occurrence of plant fossils, especially of charcoalified wood and their radiocarbon ages (e.g. Shotton et al. 1968, 1969, 1970; Shotton and Williams 1971, 1973; Shotton et al. 1974; Moore and Rubin 1991), but neglecting the taxonomical and systematic potential of these fossils. The literature dealing with the volcanic history of São Miguel island reports numerous palaeobotanical remains: Booth et al. (1978) presents a tephrochronological study of several volcanoes, aided by Holocene radiocarbon dates obtained from mummified or charcoalified wood, and in the selected lithological sections points out the presence of peat, charcoal and plant casts. Moore (1991) refined the volcano-stratigraphy of São Miguel with 62 new radiocarbon dates, mainly obtained from charcoalified plants associated to pyroclastic flows (Moore and Rubin 1991). Another source of information are citations of unpublished theses that mention plant fossils like Ponte (2013) citing the work by Pacheco (1995), reporting the presence of stems and leaf impressions in the Furnas $\mathrm{C}$ deposit or the citation of several radiocarbon dates by Wallenstein (1999) obtained from charcoalified wood. Pacheco (2001) and Guest et al. (2015) illustrate the same
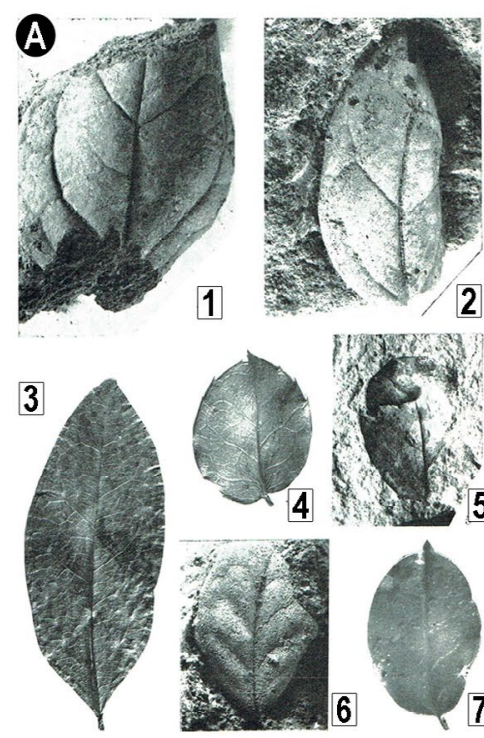
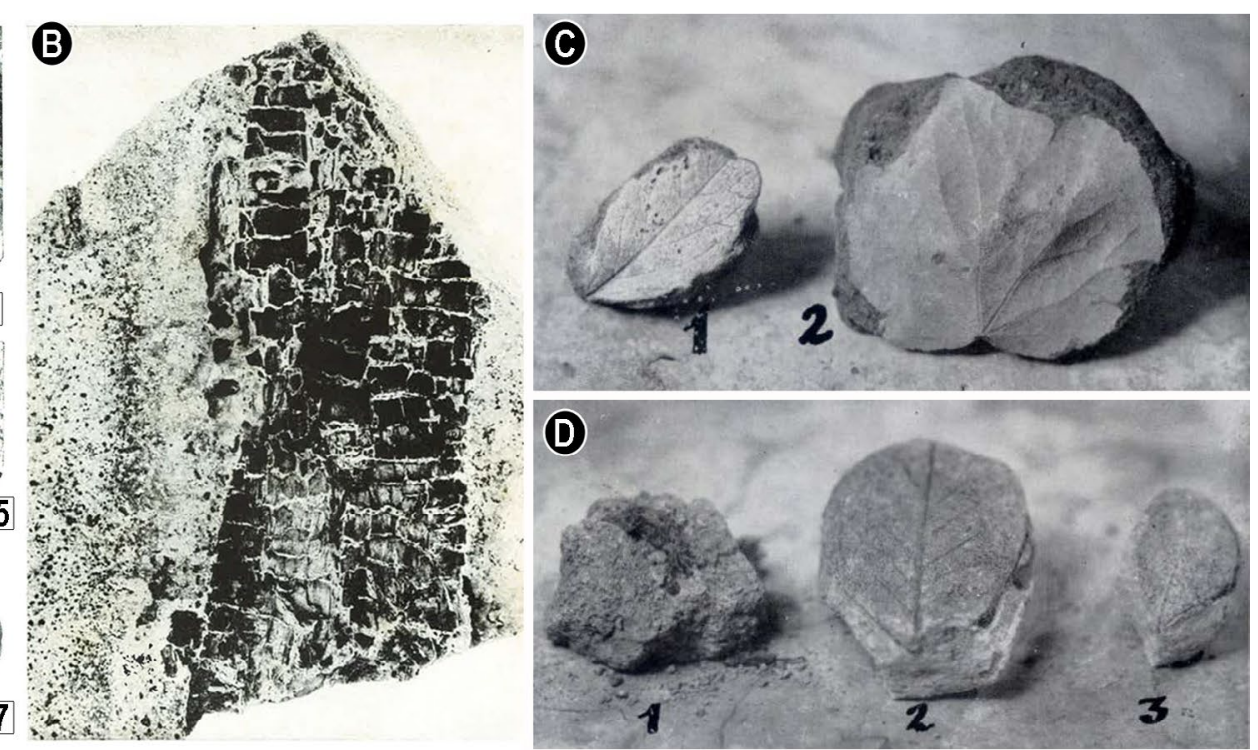

Figure 4. Examples of macrofossils described between 1960 and 1970 for several islands of the Azores. (A) Plate XII from Diniz (1962) 1 and 2: O. foetens leaf fossils, 3: O. foetens leaf; 5 and 6: Ilex perado, 4 and 7: I. perado leaves; (B) lava tree from Vila Lobos, Pico Island (from Forjaz et al. 1970); (C) and (D) first plant fossil illustrations from Espalamaca, Faial Island, published for the Azores by Forjaz (1960): (C) 1: P. azorica (=L. azorica), 2: H. canariensis; D) 1: Persea (=Laurus) endocarp, 2: P. azorica (=L. azorica), 3: Notelaea excelsa (=Picconia azorica?). 
leaf adpression in a tuff associated with Furnas volcanism. Ponte (2013) illustrates a pumitic deposit rich in charcoalified wood, dated by Wallenstein (1999) as having 21,340 \pm 130 years BP. Borges (2007) cites Webster (1821), Goeze (1867b) and Fouqué (1873b) for the presence of large trees trunks buried by volcanic materials. Jorge et al. (2011) illustrate a Juniperus sp. fossil trunk collected in the opening of a tunnel near Sete Cidades and a leaf impression deposited at the Carlos Machado Museum (Ponta Delgada), identified as Hedera azorica.

Recently, Góis-Marques and Menezes de Sequeira (2015) reported the re-localization of some of the fossils sent by Arruda Furtado in 1881-1882 to London. From the 16 specimens sent, only one survived. However, leaf impressions from Furnas caldera were identified in the same collection, being determined as Laurus azorica (Seub.) Franco, Woodwardia radicans (L.) Sm. and Filicopsida indet. (Góis-Marques and Menezes de Sequeira 2015). The only palaeoecological study published using pollen as a proxy is by Rull et al. (2017b). This study presents the palynological content of a sediment core from Lagoa Azul (Sete Cidades Caldera) recording 700 years of palaeoecological changes. Moreover, this paper proposes the hypothesis that São Miguel may have been colonized 150 years earlier than the official Portuguese settlement.

\section{Terceira Island}

For Terceira Island 14 references were found, with several fossil or radiocarbon localities reported for the island (Figure 3(A)). The first reference to plant fossils is given by Boid (1834) that describes the presence of a tree trunk buried near Pico da Bagacina: '... it was the trunk of a large tree, projecting out of the lower stratum of a congeries of volcanic soil ... and still retaining all its ligneous properties' (Boid 1834, p. 222). Later, Walker (1886) reports the existence of mummified trunks near Santa Bárbara, describing their use by local people:

In various parts of Terceira, and more especially in the vicinity of Santa Barbara, are occasionally found immense cedar trees embedded in deep ravines and valleys, still in perfect preservation; such a find is a God-send to the poor villagers, who instantly cut the bole up for firewood, always in these islands a short commodity amongst them. (Walker 1886, p. 253)

Guppy (1917), in his discussion about the existence in the past of large trees in the Azores, cites Walker (1886). The next reference is by Berthois (1948) with the description of a siliceous deposit located West of Biscoitos church, probably from hydrothermal genesis, were impressions and casts of stems and leaves were found. Agostinho (1949) writing about the volcanism of Monte Brasil (Angra do Heroísmo), describes the presence of leaf impressions associated to the surtseyan tuffs of Monte Brasil. The identified taxa were Persea azorica (= Laurus azorica) and Hedera canariensis (=Hedera azorica), although no palaeobotanical study to support these identifications is presented.

The production of the geological map of Terceira Island (1967-1968), culminated in the discovery of several sites of palaeobotanical interest. Zbyszewski et al. (1971) recognized a siliceous deposit similar to that described by Berthois (1948), with stems and leaves, and states the presence of $L$. azorica. Zbyszewski et al. (1971) also identifies plant fossils in Porto das Pipas, mentioning two levels with plant fossils. In the sequence of the geological mapping, Forjaz et al. (1970) published the identifications of some leaf impressions from Biscoitos including Hedera helix ssp. canariensis (Willd.) (= Hedera azorica Carrière) and Laurus azorica (Seub.) Franco. In the leaf-bed of Angra and Fanal they identify Laurus azorica (Seub.) Franco, Hedera helix ssp. canariensis (Willd.) P. Cout. (=H. azorica Carrière), Picconia azorica (Tutin) Knobl., Pteris serrulata Forsk (= P. incompleta Cav.) and Myrica faya Ait. [= Morella faya (Aiton) Wilbur].

Radiocarbon dates obtained from charcoalified trunks from Terceira Island were first reported in the 1970s (Zbyszewski et al. 1971; Shotton and Williams 1973; Shotton et al. 1974). Self (1976) uses the published dates to interpret the volcano-stratigraphy and chronology of the ignimbrite deposits in Terceira Island. The next reference is from Calvert et al. (2006), who obtained 23 radiocarbon dates from 'charcoal ... collected from within pyroclastic flow, pyroclastic fall, and surge deposits and in buried soils beneath lava flows as well as fragments entirely enclosed within lava flows from several points of the island' (Calvert et al. 2006, p. 111).

Recently, Gertisser et al. (2010) presented a stratigraphic and chronological study of the ignimbrite deposits from Terceira Island adding 14 new radiocarbon dates $(20,500 \pm 500$ years BP up to $>46,700$ years $\mathrm{BP}$ ) using charcoalified plants from paleosols. The two levels with plant fossils in the bay of Angra do Heroísmo (Zbyszewski et al. 1971) are related to the ignimbrite deposits described by Gertisser et al. (2010) and to the younger (yet undated) surtseyan eruption of Monte Brasil.

The most recent references to plant fossils are presented by Daza and Bustillo $(2014,2015)$ in the study of speleothems from volcanic caves of Terceira Island, who present several examples of plant permineralization by silica. In the Branca Opala lava tube, Daza and Bustillo (2014), describe stromatolites and silicified plants inside and outside the cave, (along Ribeira dos Biscoitos). SEM photomicrographs show that these plant fossils (leaves, including Bryophyte remains) have preserved anatomical detail, although identification was out of the scope of their work. Daza and Bustillo (2015) describe three types of root-associated stalactites (rootsicles), probably from brambles (Rubus sp.) and ferns, some showing anatomical preservation, in the Galeria da Queimada lava tube.

A short survey in the Fanal sea cliff (West of Angra do Heroísmo; Figure 5(A)) confirmed the presence of two layers with leaf fossils, as described by Zbyszewski et al. (1971): leaf impressions associated with Monte Brasil tuff (Agostinho 1949; Figure 5(C)), and leaf compressions and adpressions associated with an older ash tuff (Figure 5(B)). Further fieldwork is needed in Fanal cliff, although a development project currently underway may prevent future more detailed studies in that locality. Finally, we must refer the existence of a collection of plant fossils at the Museu Vulcanospeleológico - Os Montanheiros (Angra do Heroísmo), where a lava tree mould from Pedreira da Barraca (Figure 5(D); F. Fernando Pereira pers. comm.), and leaf impressions from Monte Brasil tuff are in display.

\section{São Jorge Island}

There are three papers reporting plant fossils from São Jorge Island, mainly from its central part (Figure 3(B)). Forjaz et al. (1970) mention the existence of a lava tree mould in the basalts 

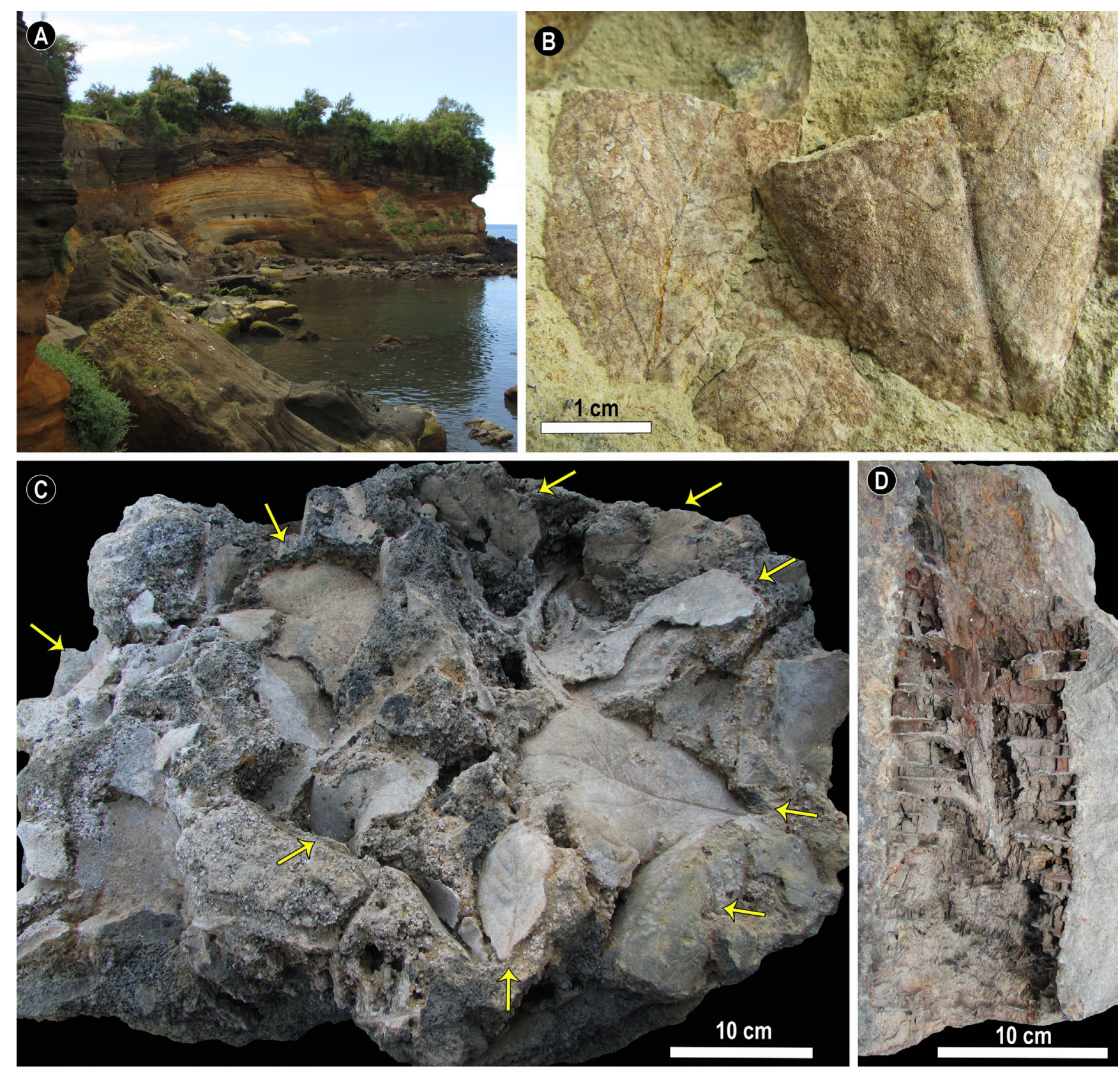

Figure 5. Examples of plant fossils from Terceira Island. (A) Fanal bay (West of Angra do Heroísmo), where plant fossils are found within tuffs; (B) Unidentified leaf compressions from the lower yellow tuffs; (C) surtseyan lapilli-tuff block from the upper unit (Monte Brasil) with several leaf impressions, observed in the Museu Vulcanoespeleológico in Angra do Heroísmo; D) lava tree mould from Pedreira da Barraca from the same museum.

of the village of Urzelina. It is not clear if this finding is related to the basaltic flows of the 1808 eruption or to older lava flows. Plant macrofossils (mummified and charcoalified wood), peat and paleosols were used to obtain radiocarbon ages published by Madeira et al. (1998) and by Madeira and Brum da Silveira (2003).

\section{Pico Island}

In Pico Island, we found eight references to leaf beds and plant fossils used for radiocarbon dating (Figure 3(A)). Historically, Frutuoso (1590a), while describing Pico Island at the end of the sixteenth century, refers to the existence of buried trunks of yew (Taxus baccata), that were excavated by peasants due to the high value of the timber, as it was forbidden to cut yews without the royal authorization (Frutuoso 1590a, p. 132). Frutuoso (1590a) was probably describing mummified trunks buried by landslides. The next reference is by Forjaz and Monjardino (1964), who present a preliminary study of a leaf bed where the following species were identified: Notelaea excelsa Webb [=Picconia azorica (Tutin) Knobl.]; Laurus azorica (Seub.) Franco, Pittosporum sp. (undulatum Vent.?) (an alien species for Azores), Asplenium sp., Asplenium sp. (obovatum Viv.?) and Dryopteris azorica (Christ) Alston. Forjaz et al. (1970), describe the presence of lava trees moulds in Ponta do Moinho (Cais do Pico) and charcoalified trunks in São João, Vila Lobos (Figure 4(B)) and Madalena. Nunes (1999) sampled several sites for radiocarbon dating, mentioning that charcoalified trunks and branches were normally 
found in paleosols beneath pahoehoe lava flows. Other plant fossils localities are mapped by Nunes (1999), but not described in the text (e.g. Serra, Cabeço do Chão, Lajes). França (2002) states that lava tree moulds are common in Pico, and illustrates one example from an unknown locality.

The most recent studies focused on palaeopalynology of sediment cores. van Leeuwen et al. (2005), show that Selaginella kraussiana, a species thought to be an alien species to Pico Island, was native at least ca. 4000 years ago from the analysis of a core from Lagoa do Caveiro. Connor et al. (2012) published a palaeoecological study of two sediment cores, one from Lagoa do Caveiro and another from bog, allowing a temporal reconstruction of the vegetation palaeoecology of the island in the last 6000 years. The main conclusions were that anthropic impacts from the Portuguese colonization were more severe than volcanism and climate change, leading to a rapid loss of native vegetation and to the change from a state of pristine forests into an anthropomorphic landscape. Moreover, they also report that Illecebrum verticillatum $\mathrm{L}$. and Persicaria sp. considered to be alien were, in fact, native to the island.

\section{Faial Island}

For Faial Island 14 references were found, reporting several fossil beds and the use of fossil plants for radiocarbon dating (Figure 3(A)). Dionísio (1937) is the earliest author to report plant fossils for Faial. According to Forjaz (1960), the leaf fossils (Laurus sp. and Picconia sp.) collected by Dionísio were deposited in the extinct Municipal Museum of Horta. Another reference is found in Krejci-Graf et al. (1958) where a probable identification of Ilex hartungui Heer [= Vaccinium sp.; see GóisMarques et al. (2018)] was obtained from photos of the Monte da Guia tuff fossils.

The explanatory note of the geological map of Faial (Zbyszewski, Moitinho d'Almeida, et al. 1959) refers two fossil beds in Lomba da Espalamaca and Monte Carneiro. Later, Forjaz (1960) describes three leaf beds around the city of Horta (Feteira, Calço das Figueiras and Espalamaca). This publication illustrates the first leaf fossils for the Azores archipelago, and includes photographs of impressions, compressions of leaves and of an endocarp attributed to Persea sp. (possibly Laurus?). Forjaz (1960) identifies the following taxa: Cyperus longus L. (a doubtful identification and an alien species; Menezes de Sequeira et al. 2012), Hedera canariensis Willd. (= Hedera azorica Carrière), Myrica faya Ait. [Morella faya (Aiton) Wilbur], Notelaea excelsa W. et Berth, [= Picconia azorica (Tutin) Knobl.], Persea azorica Seub. [= Laurus azorica (Seub.) Franco], Blechnum spicant Wither [=Blechnum spicant (L.) Roth], Equisetaceae? and Cyperaceae? Additionally, Zbyszewski et al. (1963) in the explanatory note of the geological map of Pico Island comment the presence of plant fossils around Horta (Faial).

The following reference is given by Forjaz et al. (1970) by presenting a summary of plant fossils found in Faial, Pico, São Jorge and Terceira. For Faial, the authors cite the previous paper (Forjaz 1960), and add new localities: in Caldeira, reporting the presence of thick mummified trunks of Juniperus brevifolia; in Cedros and Salão, reporting charcoalified trunks and branches of J. brevifolia and Pittosporum sp. These authors also report the presence of unidentifiable plant fossils in Praia do Norte.
The first radiocarbon dates for Faial were published by Shotton et al. (1970) and latter Shotton and Williams (1973) using charcoal. The next reference is given by Madeira et al. (1995) where radiocarbon dates (ranging from $10.250 \pm 1770$ to $320 \pm 50$ years $\mathrm{BP}$ ) are obtained using paleosols, peat, unaltered and charcoalified wood to date and reconstruct the volcano-stratigraphy of the island. Further references to leaf impressions (fern and a dicotyledon) in a phreatomagmatic deposit located on the crater rim of Cabeço Verde cone and to a charcoal rich tuffite deposit in Norte Pequeno are given by Madeira (1998). Subsequently, references to plant fossils used to date volcanic events by radiocarbon are given in: Pacheco (2001), Madeira and Brum da Silveira (2003), Pacheco $(2001,2015)$. Another mention is made by Forjaz (2008), stating the presence of plant fossils in the localities of Pasteleiro, Feteira de Baixo and Ponta Furada, where lava tree moulds and plant fossils associated to tuffs are found. The last bibliographical records mentioning fossil plants refer to charcoalified trunks, buried by or included in the $1200 \mathrm{yr}$. BP Caldera ignimbrite, and illustrated in Madeira (2005), Coutinho et al. (2008) and Pimentel et al. (2015).

The recent survey of the volcanic deposits of the Caldeira Formation, a sequence of pyroclastic sub-plinian and phreatomagmatic trachyte deposits younger than $16 \mathrm{ka}$ BP (Madeira 1998; Madeira and Brum da Silveira 2003), allowed the identification of several sites of palaeobotanical and palaeopalynological interest. These included mummified and charcoalified trunks embedded in ignimbrite and phreatomagmatic deposits (Figure 6(A), (B)) with preserved anatomy (Figure 6(C), (D)), including xylophagous ichnoentomological traces (Figure 6(E)), leaf-beds (7(A), (B)) containing compressions, adpressions and impressions (Figure $7(\mathrm{C})-(\mathrm{H})$ ) preserved within trachytic tuffs overlying palaeosols, and paleosols with palaeopalynological potential intercalated in pumice deposits (Góis-Marques et al. in prep.).

\section{Graciosa Island}

For Graciosa Island (Figure 3(A)), there are no published palaeobotanical studies. However, four indirect references were found. In their unpublished thesis, Maund (1985) and Gaspar (1996), report radiocarbon dates based on plant fossils. Prieto et al. (2007) states the presence of lava tree moulds near Pico do Machado, in the locality of Quitadouro. Larrea et al. (2014) cite the previous works and the existence of plant fossils used for radiocarbon dating ranging from $31 \pm 0.3$ to $12.2 \pm 0.09 \mathrm{ka}$. Furthermore, Graciosa Island has an interesting terrestrial paleozoological record, with the recent description of endemic extinct taxa like Rallus sp. (Alcover et al. 2015), and Pyrrhula crassa (Rando et al. 2017). The scarcity of palaeobotanical observations in Graciosa is most probably due to the lack of field prospection.

\section{Flores Island}

For Flores Island five references were found (Figure 3(C)). The earliest reference to macrofossils for Flores is given in Guppy (1917) who quotes the presence of buried mummified logs: '... I was told ... that up to recent times the trunks were often dug up on Flores, and were used for building the small sailing craft trading between the islands.' (Guppy 1917, p. 395). 

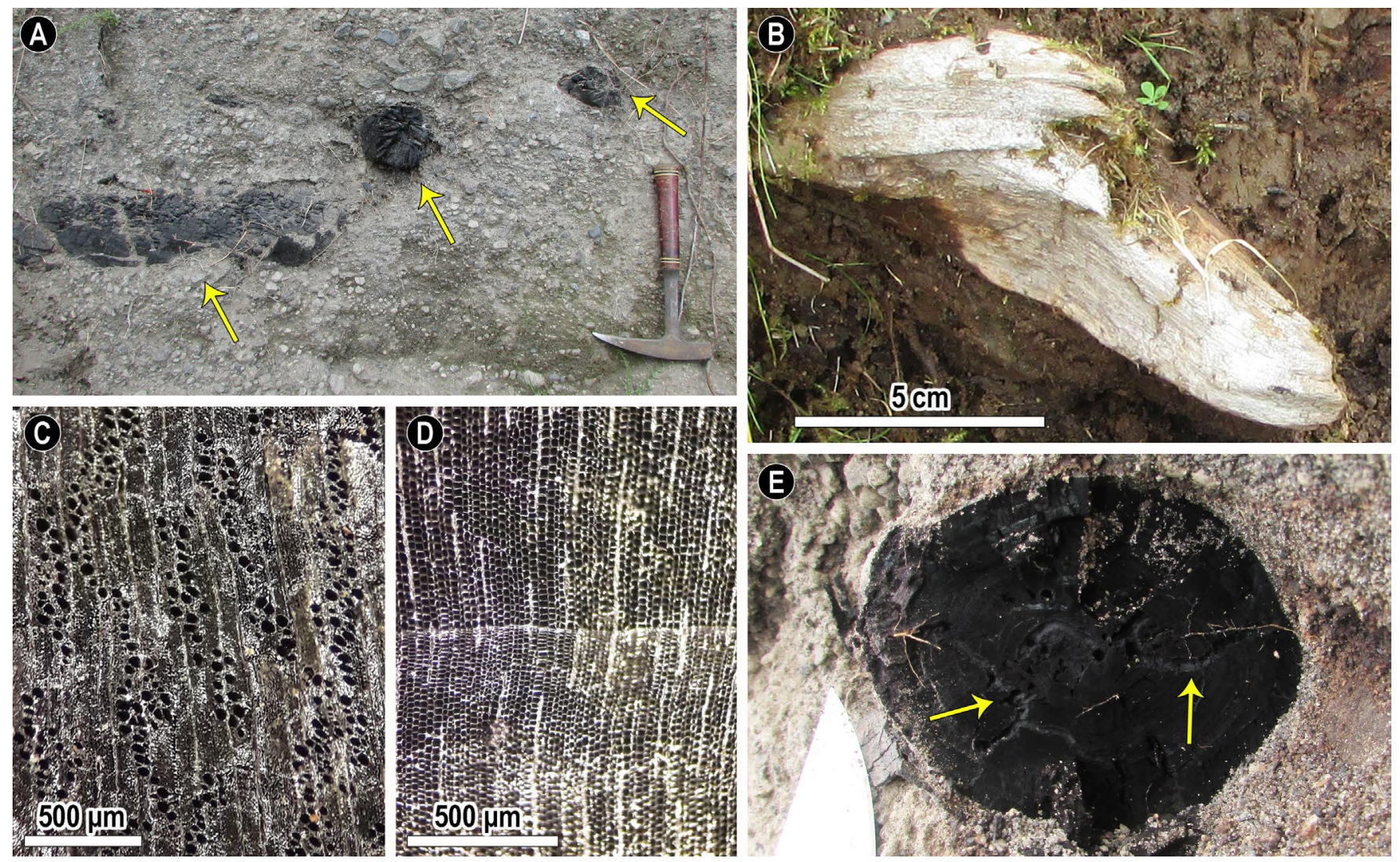

Figure 6. Examples of plant fossils from Faial Island. (A) charcoalified trunks (arrows) engulfed in a c. 1200 years BP ignimbrite deposit, near Cascalho de Cima locality; (B) mummified trunk of Juniperus sp. within a phreatomagmatic deposit near the Caldera rim; (C) and (D) Transverse sections from charcoalified trunks from the c. 1200 years BP ignimbrite showing an exquisite anatomical preservation: (C) cf. Picconia, (D) Juniperus sp.; (E) Charcoalified trunk in transverse section with ichnoentomological traces of a xylophage, found within the c. 1200 years BP ignimbrite outcrop of Fajã da Praia do Norte beach.

The next reference is given by Morisseau and Traineau (1985), that published a radiocarbon date obtained from charcoalified trunks collected at the base of pyroclastic deposits from Caldeira Comprida (2900 \pm 100 years BP) and Caldeira Funda das Lajes $(3150 \pm 100$ years BP).

\section{Corvo Island}

Corvo Island has no known palaeobotanical or palaeopalynological records published. However, preliminary palaeopalynological results of a sediment core from Caldeirão do Corvo were presented by Connor et al. (2016) at the 2nd Island Biology Symposium, held in 2016 in Terceira Island.

\section{Discussion}

\section{Historical importance}

The palaeobotanical record of the Azores Islands is abundant, and the historical analysis shows almost uninterrupted citations of direct and indirect evidence of plant fossils from all islands (Figures 2 and 3). It is important to state the range of scientific disciplines that report Azorean plant fossils, starting with papers and books of general geology or natural history from the nineteenth century (e.g. Webster 1821; Boid 1834; Hartung $1860)$ to more recent palynological approaches (e.g. Connor et al. 2012; Rull et al. 2017b) and geochemistry papers (e.g. Daza and Bustillo 2014). Historically, taxa identification (Figure 2) is rare and many identifications are given without a formal palaeobotanical description or comparison to extant taxa. Moreover, the great majority of these fossils do not correspond to collection specimens, which prevents a palaeobotanical review. Three spikes in citations are worth mentioning: a first spike in the 1880-1890 decades (corresponding to the 3 rd phase), with the identification of leaf fossils sent to the United Kingdom by Arruda Furtado (Arruda 2002); a second spike corresponding to the 1960 decade (5th phase), mainly because of the report and study of macrofloras from São Miguel, Faial, Pico and Terceira (Diniz 1962; Forjaz et al. 1970). A third spike during the current decade (corresponding to the 7th phase) corresponds to identification of fossil plant taxa (Figure 2) using pollen contents in sediments (e.g. Connor et al. 2012; Rull et al. 2017b).

The pre-scientific reference to mummified Taxus baccata trunks, buried in Pico Island by Frutuoso (1590a), is the oldest mention found for Azores Islands. Moreover, when compared with other Macaronesia archipelagos (e.g. Mitchell-Thomé 1976; Marrero 2013; Góis-Marques et al. 2014), Frutuoso's reference (1590b) can be pointed out as the first mention of a plant fossil for the Macaronesia region. The described T. baccata trunks were most probably buried by landslides, as similar deposits are still found in Pico Island associated with mummified wood. The discovery and report of plant macrofossils in the Azores Archipelago is scientifically initiated by Webster (1821) with his 

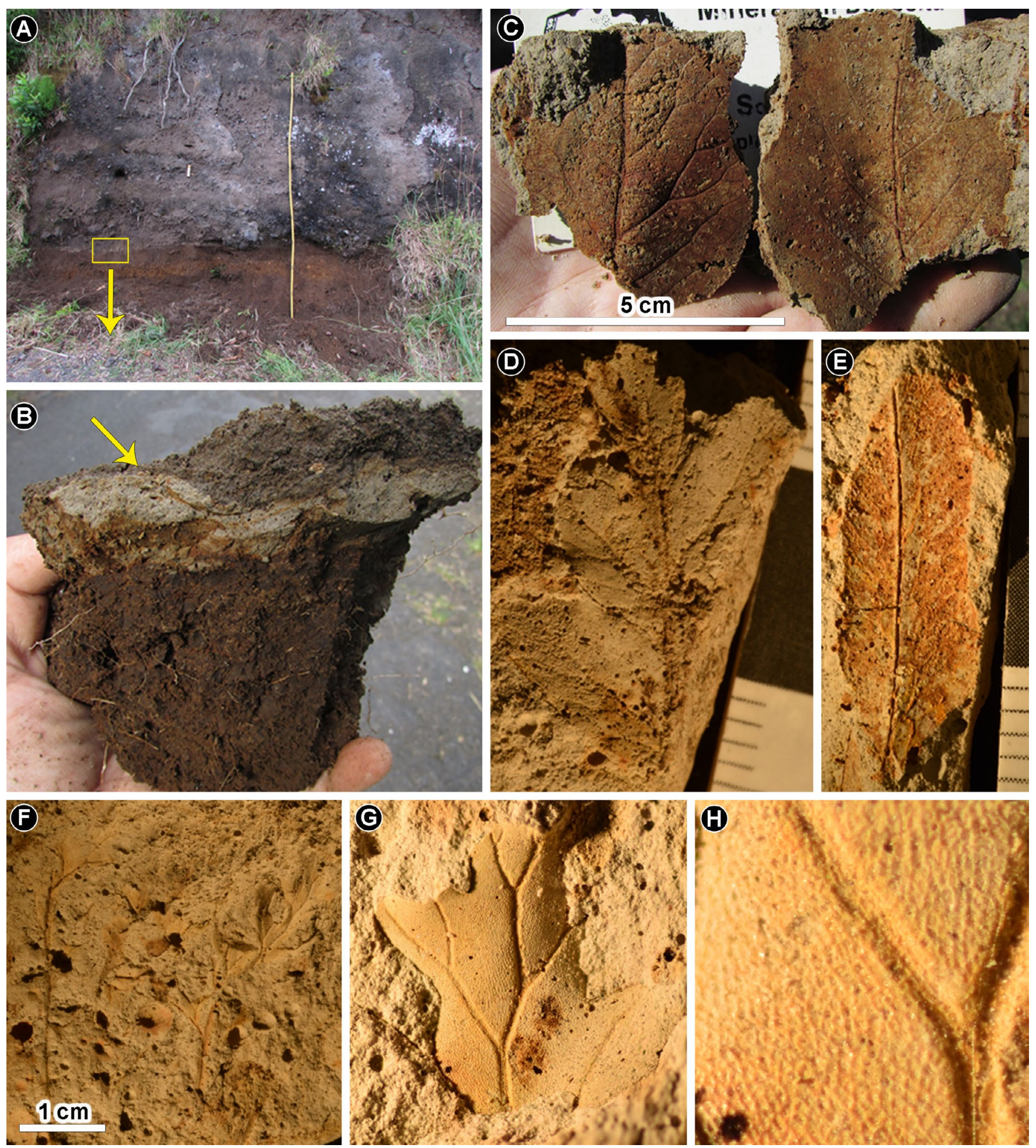

Figure 7. Joana Pires' outcrop and selected leaf palaeoflora. (A) Outcrop aspect (scale $2 \mathrm{~m}$ ); (B) Detail of the contact between the palaeosol and trachytic basal tuff (see box in (A), where the light brown trace of the leaf fossils is visible in the light grey tuff (arrow); (C) Lauroid leaf (part and counterpart); (D) frond fragment of an unidentified fern; (E) Pinnula from cf. Woodwardia; (F) cf. Anograma leptophylla fronds; (G) and (H) details of the same fern showing cuticular impression in the ash-tuff.

geological observations in São Miguel. Since then, plant macrofossils were reported, for almost all islands, most of them without a formal description, or reported as materials used for ${ }^{14} \mathrm{C}$ dating and lacking a proper collection repository. The first paleopalynological results were presented by van Leeuwen et al. (2005), even though the idea of exploring the Azorean palaeoecology can be traced back to Fries (1968).

\section{Taxonomical problems}

Taxonomical and systematic studies on Azorean plant fossils are rare and strictly the only taxonomical study of fossil flora was published more than 50 years ago by Diniz (1962). Moreover, specimens collected in the past, if still conserved in museums, need a review as there are many problematic identifications. As 
an example, Diniz (1962) identifies Pittosporum undulatum for São Miguel fossil floras, and Forjaz et al. (1970) also indicates the presence of charcoalified wood and leaf impressions from the same taxon in Pico and Faial Island. However, P. undulatum is native from Australia, being a problematic invasive species in all the Azorean Archipelago, and belonging in the top 25 of the most invasive species in Macaronesia (Silva et al. 2008). Other alien taxa identified in the same fossil flora were Phytolacca americana and Lonicera etrusca (Menezes de Sequeira et al. 2012). Another problematic case, is the identification of taxa that are native to other Macaronesia Islands. One striking case is the Stink laurel Ocotea foetens, Lauraceae native to the Madeira and Canaries Archipelagos, but introduced to the Azores (Franco 1960). This genus identification as a fossil by Diniz (1962), most probably corresponds to a misidentification, as the first comprehensive floristic checklist for the Azorean archipelago was published only in 1966 (Palhinha 1966). However, a possible confirmation of $O$. foetens in the macrofossil record of Azores, as Lauraceae pollen in the palynological record is poorly preserved due to the small amount of sporopollenin in the exine (Traverse 2007), could represent a local extinction of a tree.In other archipelagos such as Madeira, $O$. foetens is characteristic and dominant in the most important laurisilva type of forest (Capelo et al. 2004).

\section{Age of the floras}

The radiocarbon dates published to chronologically frame the volcano-stratigraphy of the islands allows us to infer a Pleistocene to Holocene age for all fossils or fossil floras described until now. Moreover, except for Santa Maria Island, all subaerial edifices of Azores are younger than 1.5 Ma (see Figure 1). However, the age of the plant remains are biased to younger ages, due to the ${ }^{14} \mathrm{C}$ dating limit of c. 50,000 yr. BP. Yet, older plant fossils do probably exist but are still unreported. An example is the Angra do Heroísmo (Terceira Island) bay, were two levels with plant fossils were identified by Zbyszewski et al. (1971), one associated with the Monte Brasil lapilli-tuff (undated) and a lower one, probably associated with two older ignimbrites deposits. The dated ignimbrites from Angra and Fanal bay, by ${ }^{14} \mathrm{C}$ and ${ }^{40} \mathrm{Ar} /{ }^{39} \mathrm{Ar}$ dating yielded ages of $39,880 \pm 800$ to $>46,700$ years BP up to $71 \pm 4 \mathrm{Ka}$ (Gertisser et al. 2010). Until the age of the lower layer containing plant fossils is resolved, the Angra do Heroísmo fossil record could represent the oldest palaeoflora recorded.

\section{Taphonomy and fossil-diagenesis}

Taphonomy of the Azorean plant fossils is mostly controlled by volcanism and by secondary volcanic manifestations. To a less extent, these are controlled by epiclastic sedimentary processes. In a broad sense, the burial and preservation of the Azorean palaeofloras can be linked to explosive and effusive volcanic activity were magma chemistry (i.e. felsic vs. mafic magma), the magma/ water interaction and magnitude are responsible for the release of materials that engulfed and entombed the palaeovegetation, preserving them as fossils. In explosive activity, pyroclastic flows can rapidly bury the vegetation, and due to the high temperatures and oxygen depletion, whole charcoalified plants are produced, associated with exceptional anatomical preservation (e.g. Faial charcoalified trunks within an ignimbrite deposit; Figure 5; see
Scott 2010); pyroclastic air-falls and phreatomagmatic explosions, usually of low temperature, can produce several fossil-diagenetic products such as leaf impressions (e.g. leaf-beds from São Miguel, Faial, and Terceira), compressions and adpressions (e.g. leaf-beds from Terceira Island and Faial), mummified and incarbonized wood (e.g. São Miguel and Faial Islands); basaltic (s.l.) lava flows can produce lava tree moulds (e.g. Terceira, São Jorge, Graciosa, Pico), some still with charcoalified remains used in ${ }^{14} \mathrm{C}$ dating (e.g. Nunes 1999; Calvert et al. 2006) or bury the vegetation with the production of charcoalified plant remains beneath the basal clinker layer (e.g. Pico, São Jorge). Secondary volcanic manifestations, like hot springs with waters saturated in silica, can promote the permineralization of plant remains, like the silicification processes described in hot springs for São Miguel (Webster 1821) or Terceira Island springs and caves (Daza and Bustillo 2014, 2015). In other Azorean islands, bird fossils were found in caves (e.g. Alcover et al. 2015; Rando et al. 2017), meaning that plant fossils may also have been preserved. Other taphonomical events that can bury palaeovegetation are landslides and mudflows (lahars) triggered by seismic or volcanic events (e.g. Faial, Pico).

Finally, paleopalynological records are known from limnic sediments from lakes or bogs, mainly resulting from the impermeabilization of volcanic calderas and craters (Connor et al. 2012; Rull et al. 2017b), or resulting from the blocking of the drainage by crater rows or fault scarps (sag ponds).

\section{Palaeoecological implications and future perspectives}

Explosive volcanism in Azores, and specially the products of the sub-plinian eruptions promote the preservation of a remarkable but still unstudied plant macrofossil record. Several authors describe plant fossils still in upright position, leaf beds associated with palaeosols and vertical trunks buried by tuff and ignimbrite deposits (e.g. Webster 1821; Forjaz 1960; Diniz 1962). From a palaeoecological perspective, these fossils represent palaeophytocenosis preserved in situ or $\mathrm{T}^{0}$ assemblages, were autochthonous and paraautochthonous plant associations are found (DiMichele and Falcon-Lang 2011 and references therein). As an example, the 1200 year BP sub-plinian eruption covered an extensive area of Faial Island (Madeira et al. 1995; Pacheco 2001; Pimentel et al. 2015), preserving within or below the pyroclastic deposits, an exceptional plant fossil record (Figures 5 and 6). The volcanic eruption allowed the preservation of a spatial snapshot of the palaeovegetation. The sampling of the preserved autochthonous fossils from multiple outcrops, ranging from sea level to the volcano summit, will allow gathering quantitative and qualitative information on the palaeodiversity and paleoecology, and these can be tested against neoecological data. Furthermore, the temporal proximity of the 1200 years BP Faial eruption to the Portuguese colonization, has the potential to deliver data to be directly compared with the potential natural vegetation models proposed for the Azores (Dias et al. 2005; Elias et al. 2016), and to complement palaeopalynological data (Connor et al. 2012; Rull et al. 2017a, 2017b). Similar studies in volcanic areas are known from a continental context, like Burnham and Spicer (1986) that investigated a pre-volcanic eruption leaf-litter buried by the eruption of El Chichón (Mexico) by digging trenches around the volcanic deposits. They arrived at the conclusion that leaf-litters 
'preserved in accurate qualitative detail the rich composition of the surrounding forests' (Burnham and Spicer 1986, p. 161). The recurrence of sub-plinian eruptions also means that for the same island, older palaeofloras could be compared, and the resilience and recurrence of ecosystems tested.

A recent discussion, coined the 'Azorean diversity enigma' by Carine and Schaefer (2010), refers to the apparent low number of endemisms in the Azores Islands when compared with other Macaronesian Islands. These authors arrived at the conclusion that palaeoclimate stability could be preventing species to radiate. Criticism to these conclusions came from Triantis et al. (2012) who, through a biogeographical approach, explained that the island age, the small area and the environmental homogeneity could better explain the lack of diversity in the Azores. The ensuing reply by Carine et al. (2012) stated that taxonomy could still provide novelties to the Azorean flora, which has been recently proven with the description of new plants such as Aichryson santamariensis M.Moura, Carine and M. Seq. Is not implausible that, in the future, the Azorean palaeobotanical taxonomical studies could provide further evidence of plant speciation in these islands, in agreement with the endemic and extinct palaeornithological Holocene record (Rando et al. 2013, 2017; Alcover et al. 2015), therefore explaining the lack of present biodiversity by the swift loss following human settlement (Jardim and Menezes de Sequeira 2008).

The reference to silicification processes in hot-springs (e.g. Webster 1821) or within volcanic caves (e.g. Daza and Bustillo 2014) is important as this process is well known in the palaeontological record to anatomically preserve exceptional fossils (e.g. Massini et al. 2016 and references therein). These sites could harbour an accumulation of interesting plant and animal remains (see Alcover et al. 2015 for a silicified bird); however, a palaeobotanical approach to these localities is still lacking, the exception being the work by Daza and Bustillo (2014) illustrating anatomically preserved plants.

Pollen proxy to describe palaeoecological and palaeoclimatological changes from limnic sediments and bog accumulations in the Azores up to now covered a period spanning from 6000 years BP to present. These studies demonstrated a high impact of palaeoclimate fluctuations in plant communities and delivered curious results such as the demonstration that some plants, considered as introduced, were in fact native to the islands (van Leeuwen et al. 2005; Connor et al. 2012), or an eventual possible pre-Portuguese colonization of São Miguel Island (Rull et al. $2017 \mathrm{~b})$. It is important to highlight that during the description of São Miguel volcano-stratigraphy, limnic sediments were found intercalated in the pyroclastic sequence and dated at 23-27 ka BP (Moore 1991). The identification and study of these older sediments could certainly provide some light into the Pleistocene vegetation and paleoclimate in these islands.

Lastly, the palaeobotanical and palynological studies in Azores islands will bring new information for conservation and restoration of ecosystems where vegetation was almost destroyed by human activities (Nogué et al. 2017).

\section{The need of conservation of Azorean plant fossil beds}

Plant fossil beds are rarely referred as geosites when discussing Azores geodiversity (e.g. Nunes et al. 2011; Lima et al. 2014). This is expected due to the lack of recent palaeobotanical research that could provide insights into the stratigraphy, palaeodiversity and palaeoecology, vital information to pinpoint them as potential geosites with protected status. However, measures to protect, minimize and prevent future destruction plant fossil beds are needed. We propose that an urgent initial assessment and mapping of the best-known plant fossil beds (e.g. Angra do Heroísmo tuffs in Terceira; nineteenth century Arruda Furtado's plant fossil locality in São Miguel). This paleontological information should be introduced in local land-use planning and management and local authorities involved to avoid the destruction of important fossil beds, for example during construction, as researchers could be allocated to supervise and retrieve fossils in susceptible areas. Moreover, the inclusion of local museums, especially the ones devoted to natural history, could serve as repositories of these fossils, making the collections available to public exhibitions and to future research. Also, coupling divulgation and public engagement will be key to preserve the plant fossil beds and bring to light future discoveries. As a final remark, a starting point can be found in Ávila et al. (2016), where an initiative to classify and protect marine fossils localities in Santa Maria Island could be transposed to important Azorean plant fossil localities.

\section{Conclusions}

From this review, several conclusions can be retrieved: (1) the Azores Islands have an important historical record of plant fossils descriptions and citations. These records date back to Frutuoso (1590a) with the first pre-scientific palaeobotanical description for Macaronesia. Since Webster (1821), observations and citations of plant fossil-beds or isolated fossil occurrences were made, but rarely studied in detail, except for the recent palaeoecological studies (e.g. Rull et al. 2017b). Due to the need to date volcanic eruptions, plant fossils and plant rich materials such as peat, soil and sediment have been used for radiocarbon analyses, but ignored from a palaeobotanical perspective. Moreover, specimens from past studies (e.g. Diniz 1962; Forjaz et al. 1970), if still available in collections, need a revision due to problematic identifications; (2) bibliographical analysis, coupled with preliminary fieldwork in Terceira and Faial Island, shows that plant somatofossils (body fossils) are common and that ichnofossils are probably rare (one doubtful citation for Santa Maria Island). The fossil record ranges from to microfossils (i.e. palynomorphs) to macrofossils (e.g. leafs, trunks), and are preserved as mummifications, charcoalifications, compressions, adpressions, impressions, permineralizations and moulds; (3) the array of the cited plant fossils was seldom studied under a palaeobotanical light. Future studies have the potential to convey new palaeobiological and palaeoecological information, as many have good anatomical information preserved (e.g. charcoalifications and permineralizations with cellular preservation, leaf fossils with cuticles); (4) plant taphonomy is mainly the result of explosive volcanism, with the products of sub-plinian and phreatomagmatic eruptions covering large portions of the islands and, thus bury extensive areas of vegetation (e.g. Faial Island). Effusive volcanism, secondary volcanic manifestations (e.g. hot springs), and sedimentary processes also contribute for fossil preservation; (5) the taphonomical characteristics of explosive volcanism led to the preservation of autochthonous and allochthonous fossil 
associations. Although allochthonous assemblages can give us information about past biodiversity, the autochthonous assemblages can bring new light into island vegetation science, as these $\mathrm{T}^{0}$ fossil communities can provide an undisturbed snapshot of the past insular ecosystem; (6) the potential information can lead to important developments in descriptive palaeodiversity (e.g. new taxa), and palaeovegetation types; the recurrent explosive volcanism in some islands may contribute to test vegetation resilience after large eruptive episodes. Holocene in situ macrofossil record coupled with palynological studies will also play an important role in reconstructing the pre-settlement vegetation, adding important information for conservation; (7) volcanic activity creates features such as calderas, craters and caves that act as natural sedimentary traps, were limnic sediments containing a palynological record are preserved; (8) analysis of limnic sediment cores from the Azores has, until now, allowed describing ca. 6000 years of climatic variation and vegetation response. Anthropogenic impacts in native flora and vegetation, following the Portuguese settlement, can be evaluated.

It is safe to say that, although in recent years the palaeoecological studies in Azores had a great development, these oceanic islands are still mostly unexplored, and that fossil novelties are certainly buried beneath volcanic deposits awaiting to be discovered and properly studied.

\section{Acknowledgements}

We would like to thank Fernando Pereira, for allowing the access to the fossil collections of the Volcano-speleological Museum, Manuel Steinbauer for field assistance in Terceira, Adriano Pimentel for indicating key outcrops in Faial, Juanma Rubiales for support with charcoal analysis and to Carlos Marques da Silva for constructive comments and discussion that enriched an early draft of this paper. We also want to express our gratitude to the three anonymous reviewers and their invaluable comments that improved this manuscript. CAG-M would like to acknowledge financial support from ARDITI - Regional Agency for the Development of Research, Technology and Innovation, project M1420- 09-5369-FSE-000001- PhD grant and JM to FCT-project UID/GEO/50019/2013-Instituto Dom Luiz.

\section{Disclosure statement}

No potential conflict of interest was reported by the authors.

\section{Funding}

This work was supported by ARDITI - Regional Agency for the Development of Research, Technology and Innovation, project [M1420- 09-5369-FSE000001- PhD grant]; and FCT-project [UID/GEO/50019/2013-Instituto Dom Luiz].

\section{ORCID}

Carlos A. Góis-Marques (iD http://orcid.org/0000-0002-0255-7641

Lea de Nascimento iD http://orcid.org/0000-0003-1085-2605

Miguel Menezes de Sequeira (iD http://orcid.org/0000-0001-9728-465X

José María Fernández-Palacios (iD) http://orcid.org/0000-0001-9741-6878 José Madeira (iD http://orcid.org/0000-0003-4729-8994

\section{References}

Abdel-Monem A, Fernandez LA, Boone GM. 1975. K-Ar ages from the eastern Azores Group (Santa Maria, S. Miguel and the Formigas islands). Lithos. 8:247-254.
Agostinho J. 1949. O monte Brasil: esboço monográfico. Açoreana, Boletim da Sociedade Afonso Chaves. 4:343-355.

Aiton W. 1789. Hortus Kewensis: a Catalogue of the plants cultivated in the Royal Botanic Garden at Kew. Vol. III. London.

Alcover JA, Pieper H, Pereira F, Rando JC. 2015. Five new extinct species of rails (Aves: Gruiformes: Rallidae) from the Macaronesian Islands (North Atlantic Ocean). Zootaxa. 4057(2):151-190.

Amen R. 2002. Estudo da jazida fóssil da Praínha, Santa Maria, Açores. Ponta Delgada: Tese de Licenciatura. Universidade dos Açores; p. 51.

Anderson CL, Channing A, Zamuner AB. 2009. Life, death and fossilization on Gran Canaria - implications for Macaronesian biogeography and molecular dating. J Biogeograp. 36(12):2189-2201.

Arruda LM. 2002. Correspondência científica de Francisco de Arruda Furtado. Instituto cultural de Ponta Delgada. 787 pp.

Ávila SP, Madeira P, Zazo C, Kroh A, Kirby M, da Silva CM, Cachão M, de Frias Martins AM. 2009. Palaeoecology of the Pleistocene (MIS 5.5) outcrops of Santa Maria Island (Azores) in a complex oceanic tectonic setting. Palaeogeograp Palaeoclimatol Palaeoecol. 274(1):18-31.

Ávila S, Rebelo A, Medeiros A, Melo C, Gomes C, Bagaço L, Madeira P, Borges PA, Monteiro P, Cordeiro R, et al. 2010. Os fósseis de Santa Maria (Açores): A jazida da Prainha. Lagoa: OVGA - Observatório Vulcanológico e Geotérmico dos Açores. 105 pp.

Ávila SP, Cachão M, Ramalho RS, Botelho AZ, Madeira P, Rebelo AC, Cordeiro R, Melo C, Hipólito A, Ventura MA, et al. 2016. The Palaeontological Heritage of Santa Maria Island (Azores: NE Atlantic): a Re-evaluation of Geosites in GeoPark Azores and their use in Geotourism. Geoheritage. 8(2):155-171.

Azevedo JMM, Portugal Ferreira MR. 2006. The volcanotectonic evolution of Flores Island, Azores (Portugal). J Volcanol Geotherm Res. 156(12):90-102.

Bensaúde A. 1892. Note sur un tuf diabasique contenant des fossiles Communicações da Commissão de Trabalhos Geológicos de Portugal. Tomo. II(II):228-231.

Berthois L. 1948. Sur une roche siliceuse de Biscoutos, Ile Terceira, Açores. Açoreana. IV(3):240-262.

Boid E. 1834. A description of the Azores or Western Islands. London: Bull and Churton, Holles Street; p. 373.

Booth B, Croasdale R, Walker GPL. 1978. A Quantitative Study of Five Thousand Years of Volcanism on Sao Miguel, Azores. Philosoph Trans R Soc London Series A Math Phys Sci. 288(1352):271-319.

Borges PMdLC. 2007. O desenho do território e a construção da paisagem na ilha de S. Miguel nos Açores, na $2^{\text {a }}$ metade do século XIX, através de um dos seus protagonistas. [Unpublished $\mathrm{PhD}$ thesis]. Coimbra: Faculdade de Ciências e Tecnologia da Universidade de Coimbra, 550 $\mathrm{pp}$

Borregaard MK, Amorim IR, Borges PAV, Cabral JS, Fernández-Palacios JM, Field R, Heaney LR, Kreft H, Matthews TJ, Olesen JM, et al. 2017. Oceanic island biogeography through the lens of the general dynamic model: assessment and prospect. Biol Rev. 92(2):830-853.

Burnham RJ, Spicer RA. 1986. Forest litter preserved by volcanic activity at El Chichon, Mexico: a potentially accurate record of the pre-eruption vegetation. PALAIOS. 1(2):158.

Calvert AT, Moore RB, McGeehin JP, Rodrigues da Silva AM. 2006. Volcanic history and 40Ar/39Ar and 14C geochronology of Terceira Island, Azores, Portugal. J Volcanol Geotherm Res. 156(1-2):103-115.

Canto e Castro EVPd. 1890. Ensaio sobre a bibliographia geologica dos Açores. Archivo dos Açores. 11:265-303.

Capelo J, Menezes de Sequeira M, Jardim R, Costa JC. 2004. Guia da excursão geobotânica dos V Encontros ALFA 2004 à ilha da Madeira. In: Capelo J, editor. A paisagem vegetal da ilha da Madeira Quercetea 6; p. 5-45.

Carine MA, Schaefer H. 2010. The Azores diversity enigma: why are there so few Azorean endemic flowering plants and why are they so widespread? J Biogeograp. 37(1):77-89.

Carine MA, Jones K, Moura M, Graciete Belo Maciel M, Rumsey FJ, Schaefer H. 2012. Putting biogeography's cart back behind taxonomy's horse: a response to Triantis. J Biogeograp. 39(6):1184-1187.

Chaves FA. 1908. Gisements de Diatomées fossiles à Furnas (Ile de S. Miguel). Société Portugaise des Sciences Naturelles. 2:231-255.

Connor SE, van Leeuwen JFN, Rittenour TM, Knaap WOvd, Ammann B, Björck S. 2012. The ecological impact of oceanic island colonization 
- a palaeoecological perspective from the Azores. J Biogeograp. 39(6):1007-1023.

Connor SE, Knaap WOvd, Leeuwen JFNv, Kuneš P. 2013. Holocene palaeoclimate and palaeovegetation on the islands of Flores and Pico. In: Fernández-Palacios JM, Nascimento Ld, Hernández JC, et al., editors. Climate change perspectives from the Atlantic: past, present and future. Universidad de La Laguna: Servicio de Publicaciones Universidad de La Laguna; p. 149-162.

Connor S, Gomes A, Haberle S, Knaap WOvd, Petr K, Leeuwen JFNv, Lewis T, Piva S, Porch N. 2016. Lost ecosystems of Corvo Island, Azores. In: Gabriel R, Elias RB, Amorim IR, et al., editors. Conference program and abstracts of the 2nd International Conference on Island Evolution, Ecology and Conservation: Island Biology 2016. Angra do Heroísmo: Arquipelago, Life and Marine Sciences; p. 217.

Conybeare WD. 1851. Geologia da Ilha de San-Miguel (translated by Thomas Carew Hunt). Revista dos Açores. 1(12):45-46.

Costa ACG, Hildenbrand A, Marques FO, Sibrant ALR, Santos de Campos A. 2015. Catastrophic flank collapses and slumping in Pico Island during the last $130 \mathrm{kyr}$ (Pico-Faial ridge, Azores Triple Junction). J Volcanol Geotherm Res. 302:33-46.

Coutinho R, Pimentel A, Pacheco J. 2008. Na Rota dos Vulcões - Guia Geológico da Ilha do Faial. Faial: Adeliaçor.

Daza R, Bustillo MA. 2014. Exceptional silica speleothems in a volcanic cave: a unique example of silicification and sub-aquatic opaline stromatolite formation (Terceira, Azores). Sedimentology. 61(7):21132135 .

Daza R, Bustillo MA. 2015. Allophanic and ferric root-associated stalactites: biomineralization induced by microbial activity (Galeria da Queimada lava tube, Terceira, Azores). Geol Mag. 152(3):504-520.

De La Beche HT. 1832. A geological manual. Philadelphia, PA: Carey and Lea, Philadelphia; p. 535.

Demande J, Fabriol R, Gérard A, Iundt F. 1982. Prospection géothermique des Iles de Faial et Pico (Açores). Orléans: Bureau de Recherches Géologiques et Minières. Report 82SGN003GTH.

Dias E. 2007. A Chegada dos portugueses às ilhas - o antes e o depois - Açores. In: Silva J, editor. Árvores e Florestas de Portugal: Açores e Madeira - A Floresta das Ilhas. Público: Comunicação Social SA, Fundação Luso Americana para o Desenvolvimento e Liga para a Protecção da Natureza; p. 137-164.

Dias E, Mendes C, Melo C, Pereira D, Elias R. 2005. Azores Central Islands and Flora Field Guide. Quercetea. 7:123-173.

DiMichele WA, Falcon-Lang HJ. 2011. Pennsylvanian 'fossil forests' in growth position ( $\mathrm{T}^{0}$ assemblages): origin, taphonomic bias and palaeoecological insights. J Geol Soc. 168(2):585-605.

Diniz F. 1962. Vegetais dos tufos vulcânicos da ilha de São Miguel, Açores. Comunicações dos Serviços Geológicos de Portugal. Tomo XLVI:317329.

Dionísio M. 1937. Costumes Açorianos. Angra do Heroísmo: Tip InsularJoão Vieira, Angra do Heroísmo.

Drouet H. 1857. Rapport à Sa Majesté le Roi de Portugal sur un voyage d'exploration scientifique aux îles Açores, exécuté par MM. Arthur Morelet et Henri Drouët pendant le printemps et lété de 1857 Mémoires de la Société d'Agriculture, des Sciences. Arts et Belles-Lettres du Département de l’Aube. 9(45):5-33.

Drouet H. 1866. Catalogue de la flore des iles Açores précédé de L'itinéraire d'un voyage dans cet archipel. Paris: J.-B. Bailliére and fils; p. 153.

Elias RB, Gil A, Silva L, Fernández-Palacios JM, Azevedo EB, Reis F. 2016. Natural zonal vegetation of the Azores Islands: characterization and potential distribution. Phytocoenologia. 46(2):107-123.

Elwes HJ, Henry A. 1910. The trees of the Great Britain and Ireland. Vol. 5. Edinburgh: Privately Printed; p. 1333.

Fernandes V. 1508. Das ilhas do Mar Oceano (Separata do "Manuscrito Valentim Fernandes-1508”). Academia de. História. 7(1940):106-119.

Forjaz VH. 1960. Notícia de alguns fósseis na ilha do Faial. Atlantida IV(1):30-40.

Forjaz VH. 2008. Na rota dos vulcões da ilha do Faial. Ponta Delgada: Observatório Vulcanológico e Geotérmico dos Açores.

Forjaz VH, Monjardino JL. 1964. Notícia preliminar sobre os tufos vulcânicos fossilíferos de Santo António, Ilha do Pico, Açores. Atlantida. VIII(3):179-184.
Forjaz VH, Mojardino JL, Fernandes NSM. 1970. Contribuição para o estudo das jazidas fossilíferas das ilhas do Faial, Pico, S. Jorge e Terceira (Açores). Comunicações dos Serviços Geologicos de Portugal. Tomo LIV:27-37.

Fouqué F. 1873a. Voyages Géologiques aux Açores I. L' ile de Terceire. Revue des Deux Mondes. Cent Troisieme:40-65.

Fouqué F. 1873b. Voyages Géologiques Aux Açores II. Graciosa, Pico et Fayal. Revue des Deux Mondes. Cent Quatrième:617-644.

Fouqué F. 1873c. Voyages Géologiques aux Açores III. Les cultures de SanMiguel. Le monde organique aux Açores. Revue des Deux Mondes. Cent Quatrième:829-863.

França Z. 2002. Origem e Evolução Petrológica e Geoquímica do Vulcanismo da ilha do Pico, Açores. Ponta Delgada: Câmara Municipal de São Roque do Pico; p. 391.

França Z, Lago M, Nunes JC, Galé C, Forjaz VH, Pueyo O, Arranz E. 2006. Geochemistry of alkaline basalts of Corvo Island (Azores, Portugal): preliminary data. Geogaceta. 40:87-90.

Franco JA. 1960. Lauráceas Macaronésicas. Anais do Instituto Superior de Agronomia. 23:89-104.

Franco JA. 1971. Nova Flora de Portugal (Continente e Açores): Lycopodiaceae-Umbelliferae. Vol. 1. Lisboa.

Fries M. 1968. Organic Sediments and Radiocarbon Dates from Crater Lakes in the Azores. Geologiska Föreningen i Stockholm Förhandlingar. 90(3):360-368.

Frutuoso G. 1590. Livro Quarto das Saudades da Terra. Ponta Delgada: Instituto Cultural de Ponta Delgada (edition 1998).

Frutuoso G. 1590. Livro Sexto das Saudades da Terra. Ponta Delgada: Instituto Cultural de Ponta Delgada (edition 1998).

Gaspar JL. 1996. Ilha Graciosa (Açores): História vulcanológica e avaliação do hazard [Unpublished PhD thesis]. Portugal: University of Azores.

Gente P, Dyment J, Maia M, Goslin J. 2003. Interaction between the Mid-Atlantic Ridge and the Azores hot spot during the last 85 Myr: emplacement and rifting of the hot spot-derived plateaus. Geochem Geophys Geosyst. 4(10):1-23.

Gertisser R, Self S, Gaspar JL, Kelley SP, Pimentel A, Eikenberg J, Barry TL, Pacheco JM, Queiroz G, Vespa M. 2010. Ignimbrite stratigraphy and chronology on Terceira Island, Azores. Geol Soc Am Special Papers. 464:133-154.

Goeze E. 1867a. Foreign Correspondence, Busaco, July 26th- Cupressus glauca. The Gardeners' Chronicle and Agricultural Gazette. London: Bradbury, Evans; p. 929.

Goeze E. 1867b. A Ilha de S Miguel e o Jardim Botânico de Coimbra. Coimbra: Imprensa da Universidade.

Góis-Marques CA. 2013. Paleobotânica da Ilha da Madeira: Inventário e Revisão da Macroflora Fóssil de São Jorge e Porto da Cruz [Unpublished MSc. thesis]. Lisboa: Faculdade de Ciências da Universidade de Lisboa, $144 \mathrm{pp}$.

Góis-Marques CA, Menezes de Sequeira M. 2015. Darwin, Hooker and Arruda Furtado and the palaeobotany of Azores: rediscovering the first collections. Rev Palaeobot Palynol. 221:47-51.

Góis-Marques CA, Menezes de Sequeira M, Madeira J. 2014. Palaeobotany of Madeira Island: historical perspective of the leaf-beds and collections of S. Jorge and Porto da Cruz. Silva Lusitana. No especial:87-108.

Góis-Marques CA, Madeira J, Menezes de Sequeira M. 2018. Inventory and review of the Mio-Pleistocene São Jorge flora (Madeira Island, Portugal): palaeoecological and biogeographical implications. J Syst Palaeontol. 16(2):159-177.

Guest JE, Pacheco JM, Cole PD, Duncan AM, Wallenstein N, Queiroz G, Gaspar JL, Ferreira T. 2015. Chapter 9 The volcanic history of Furnas Volcano, São Miguel, Azores. Geol Soc London Mem. 44(1):125-134.

Guppy HB. 1914. Notes on the Native Plants of the Azores as Illustrated on the Slopes of the Mountain of Pico. Bull Miscell Inf R Bot Gardens Kew. 1914(9):305-321.

Guppy HB. 1917. Plants, seeds, and currents in the West Indies and Azores: the results of investigations carried out in those regions between 1906 and 1914. London: Williams and Norgate.

Hartung G. 1860. Die Azoren in iheer äusseren erscheinung und nach ihrer geognostischen natur. Leipzig: verlag von Wihelm Engelmann.

Hildenbrand A, Madureira P, Marques FO, Cruz I, Henry B, Silva P. 2008. Multi-stage evolution of a sub-aerial volcanic ridge over the last 
1.3 Myr: S. Jorge Island, Azores Triple Junction. Earth Planet Sci Lett. 273(3-4):289-298.

Hildenbrand A, Marques FO, Costa ACG, Sibrant ALR, Silva PF, Henry B, Miranda JM, Madureira P. 2012. Reconstructing the architectural evolution of volcanic islands from combined $\mathrm{K} / \mathrm{Ar}$, morphologic, tectonic, and magnetic data: The Faial Island example (Azores). J Volcanol Geotherm Res. 241-242:39-48.

Hunt C. 1845a. A description of the Island of St. Michael (Azores). J R Geograph Soc London. 15:268-296.

Hunt C. $1845 \mathrm{~b}$. A description of the Island of St. Mary (Azores). J R Geograph Soc London. 15:258-268.

Jardim R, Menezes de Sequeira M. 2008. As plantas vasculares (Pteridophyta e Spermatophyta) dos arquipélagos da Madeira e das Selvagens. In: Borges PAV, Abreu C, Aguiar AMF, et al., editors. Listagem dos fungos flora e fauna terrestre dos arquipélagos da Madeira e Selvagens. Funchal e Angra do Heroísmo: Direcção Regional do Ambiente da Madeira e Universidade dos Açores; p. 181-207.

Johnson CL, Wijbrans JR, Constable CG, Gee J, Staudigel H, Tauxe L, Forjaz V-H, Salgueiro M. 1998. 40Ar/39Ar ages and paleomagnetism of São Miguel lavas, Azores. Earth Planet Sci Lett. 160(3):637-649.

Jorge JC, Moura M, Neto AI, Gabriel R, Constância JP, Silva L. 2011. Exposição: À descoberta da História Botânica dos Açores: As plantas e os cientistas. Ponta delgada: CIBIO Açores.

Kent AH. 1900. Veitch's manual of the coniferae. London: James Veitch and Sons.

Krejci-Graf K, Frenchen J, Wetzel W, Colom G. 1958. Gesteine und fossilien von den Azoren. Senckenbergiana Lethaea. 39:303-351.

Larrea P, Wijbrans JR, Galé C, Ubide T, Lago M, França Z, Widom E. 2014. $40 \mathrm{Ar} / 39 \mathrm{Ar}$ constraints on the temporal evolution of Graciosa Island, Azores (Portugal) [journal article]. Bull Volcanol. 76(2):796.

Lima EA, Nunes JC, Costa MP, Machado M. 2014. Basis for the geological heritage management in the Azores Archipelago (Portugal). J Integr Coastal Zone Manage. 14(2):301-319.

van Leeuwen JFN, Schäfer H, Knaap WOvd, Rittenour T, Björck S, Ammann B. 2005. Native or introduced? Fossil pollen and spores may say. An example from the Azores Islands. In: Nentwig Wea, editor. Biological invasions - from ecology to control; p. 27-34.

Madeira J. 1998. Estudos de Neotectónica nas ilhas do Faial, Pico e S. Jorge: uma contribuição para o conhecimento geodinâmico da junção tripla dos Açores [Unpublished PhD thesis]. Lisboa: Universidade de Lisboa.

Madeira J. 2005. The volcanoes of Azores Islands: a world-class heritage. Examples from Terceira, Pico, and Faial Islands. Lisboa: Lattex, Laboratório de Tectonofísica e Tectónica Experimental, Universidade de Lisboa.

Madeira J, Brum da Silveira A. 2003. Active tectonics and first paleoseismological results in Faial, Pico and S. Jorge islands (Azores, Portugal). Annals of Geophysics. 46(5):733-771.

Madeira J, Soares Monge, Brum Da Silveira A, Serralheiro A. 1995. Radiocarbon Dating Recent Volcanic Activity on Faial Island (Azores). Radiocarbon. 37(2):139-147.

Madeira J, Brum da Silveira A, Serralheiro A, Monge Soares A, Rodrigues CF. 1998. Radiocarbon ages of recent volcanic events from the Island of S. Jorge (Azores). Comunicações do IGM. 84:A189-A192.

Marrero Á. 2013. Aportaciones a la flora pliocena de la isla de Gran Canaria: avances a los estudios florísticos y paleoambientales. Vieraea. 41:371-384.

Massini JG, Escapa IH, Guido DM, Channing A. 2016. First Glimpse of the Silicified Hot Spring Biota from a New Jurassic Chert Deposit in the Deseado Massif, Patagonia, Argentina. Ameghiniana. 53(2):205-230.

Maund JG. 1985. The volcanic geology, petrology and geochemistry of Caldeira volcano, Graciosa, Azores and its bearing on contemporaneous felsic-mafic oceanic island volcanism [Unpublished $\mathrm{PhD}$ thesis]. UK: University of Reading.

Menezes de Sequeira M, Espírito-Santo D, Aguiar C, Capelo J, Honrado J. 2012. Checklist da Flora de Portugal (Continental, Açores e Madeira). Lisboa: Associação Lusitana de Fitossociologia.

Mitchell-Thomé R, editor. 1976. Geology of the Middle Atlantic islands. Berlin: Gebrüder Borntraeger.

Moore RB. 1991. Geology of Three Late Quaternary Stratovolcanoes on Sao Miguel, Azores. vol 1900. U.S. Geological Survey Bulletin.
Moore RB, Rubin M. 1991. Radiocarbon dates for lava flows and pyroclastic deposits on São Miguel, Azores. Radiocarbon. 33(1):151-164.

Morisseau M, Traineau H. 1985. Mise en évidence d'une activité hydromagmatique holocène sue l'île de Flores (Açores). Comptes Rendus de l'Académie des Sciences série II. 301(18):1309-1314.

Mouzinho de Albuquerque LdS, Menezes IPdC. 1826. Observações sobre a ilha de São Miguel recolhidas pela commissão enviada à mesma ilha em Agosto de 1825. Lisboa: Impressão Régia.

Nogué S, Nascimento Ld, Froyd CA, Wilmshurst JM, Boer EJd, Coffey EED, Whittaker RJ, Fernández-Palacios JM, Willis kJ. 2017. Island biodiversity conservation needs palaeoecology. Nat Ecol Evol. 1(19):0181.

North FJ. 1933. Dean Conybeare, Geologist. Rep Trans Cardiff Nat Soc. 66:15-68.

Nunes JCC. 1999. A actividade vulcânica na ilha do Pico do Plistocénico Superior ao Holocénico: mecanismo eruptivo e hazard [Unpublished $\mathrm{PhD}$ thesis]. Açores: Universidade dos Açores.

Nunes JC, Lima EA, Ponte D, Costa MP, Castro R. 2011. Azores Geopark application. Horta: Azores Geopark. Available from: http://www. azoresgeopark.com/media/docs/candidatura_ga/Application.pdf.

Pacheco J. 1995. Caracterização do depósito vulcânico Furnas-C e seu contributo para a análise do hazard associado à actividade do vulcão das Furnas [Tese de Progressão na Carreira de Investigação]. Azores: Universidade dos Açores.

Pacheco J. 2001. Processos associados ao desenvolvimento de erupções vulcânicas hidromagmáticas explosivas na ilha do Faial e sua interpretação numa perspectiva da avaliação do hazard e minimização do risco [Unpublished PhD thesis]. Azores: Universidade dos Açores.

Pacheco JM. 2015. 14C ages of the last eruptive stage of Faial Island Caldeira Volcano. Radiocarbon. 57(5):1021-1027.

Pacheco JM, Ferreira T, Queiroz G, Wallenstein N, Coutinho R, Cruz JV, Pimentel A, Silva R, Gaspar JL, Goulart C. 2013. Notas sobre a geologia do arquipélago dos Açores. In: Dias R, Araújo A, Terrinha $\mathrm{P}$, et al., editors. Geologia de Portugal. Escolar Editora; p. 595-690.

Palhinha R. 1966. Catálogo das plantas vasculares dos Açores. Lisbon: Sociedade de Estudos Açorianos Afonso Chaves (revised and prepared for publication by A. R. Pinto da Silva).

Pimentel A, Pacheco J, Self S. 2015. The $\sim 1000$-years BP explosive eruption of Caldeira Volcano (Faial, Azores): the first stage of incremental caldera formation. Bull Volcanol. 77(5):1-26.

Pinto MS, Bouheiry A. 2007. The German geologist Georg Hartung (1821-1891) and the geology of the Azores and Madeira islands. In: Jackson PNW, editor. Four centuries of geological travel: the search for knowledge on foot, bicycle, sledge and camel. London: Geological Society (London, Special Publications); p. 229-238.

Ponte DdJF. 2013. Contribuição para o conhecimento das sequências eruptivas dos vulcões do Fogo e das Furnas, Entre Ribeirinha e Lomba da Maia, São Miguel (Açores) [Unpublished MSc. thesis]. Ponta Delgada: Universidade dos Açores.

Prieto R, Ferraz R, Luís S, Pereira S, Nunes JC, Dores VR. 2007. Candidatura da Ilha Graciosa a Reserva da Biosfera (v. 34). Governo dos Açores.

Ramalho RS, Helffrich G, Madeira J, Cosca M, Thomas C, Quartau R, Hipólito A, Rovere A, Hearty PJ, Ávila SP. 2017. Emergence and evolution of Santa Maria Island (Azores) - The conundrum of uplifted islands revisited. Geol Soc Am Bull. 129(3-4):372-390.

Rando JC, Alcover JA, Olson SL, Pieper H. 2013. A new species of extinct scops owl (Aves: Strigiformes: Strigidae: Otus) from São Miguel Island (Azores Archipelago, North Atlantic Ocean). Zootaxa. 3647(2):15.

Rando JC, Pieper H, Olson SL, Perreira F, Alcover JA. 2017. A new extinct species of large bullfinch (Aves: Fringillidae: Pyrrhula) from Graciosa Island (Azores, North Atlantic Ocean). Zootaxa. 4282(3):567-583.

Rebelo AC, Rasser MW, Kroh A, Johnson ME, Ramalho RS, Melo C, Uchman A, Berning B, Silva L, Zanon V, et al. 2016. Rocking around a volcanic island shelf: Pliocene Rhodolith beds from Malbusca, Santa Maria Island (Azores, NE Atlantic). Facies. 62(3):22.

Rull V, Connor S, Elias R. 2017a. Potential natural vegetation and preanthropic pollen records on the Azores Islands in a Macaronesian context. J Biogeograp. 44(11):2137-2440.

Rull V, Lara A, Rubio-Inglés MJ, Giralt S, Gonçalves V, Raposeiro P, Hernández A, Sánchez-López G, Vázquez-Loureiro D, Bao R, et 
al. 2017b. Vegetation and landscape dynamics under natural and anthropogenic forcing on the Azores Islands: A 700-year pollen record from the São Miguel Island. Q Sci Rev. 159:155-168.

Ryan WBF, Carbotte SM, Coplan JO, O'Hara S, Melkonian A, Arko R, Weissel RA, Ferrini V, Goodwillie A, Nitsche F, et al. 2009. Global multi-resolution topography synthesis. Geochem Geophys Geosyst. 10(3):Q03014.

Scott AC. 2010. Charcoal recognition, taphonomy and uses in palaeoenvironmental analysis. Palaeogeograp Palaeoclimatol Palaeoecol. 291(1):11-39.

Self S. 1976. The recent volcanology of Terceira, Azores. J Geological Society. 132(6):645-666.

Seubert M. 1844. Flora Azorica: quam ex collectionibus schedisque Hochstetteri patris et filii elaboravit et tabulis XV propria manu aeri incisis illustravit. Bonnae: Apud Adolphum Marcum.

Shotton FW, Williams REG. 1971. Birmingham University Radiocarbon Dates V. Radiocarbon. 13(2):141-156.

Shotton FW, Williams REG. 1973. Birmingham University Radiocarbon Dates VII. Radiocarbon. 15(3):451-468.

Shotton FW, Blundell DJ, Williams REG. 1968. Birmingham University Radiocarbon Dates II. Radiocarbon. 10(2):200-206.

Shotton FW, Blundell DJ, Williams REG. 1969. Birmingham University Radiocarbon Dates III. Radiocarbon. 11(2):263-270.

Shotton FW, Blundell DJ, Williams REG. 1970. Birmingham University Radiocarbon Dates IV. Radiocarbon. 12(2):385-399.

Shotton FW, Williams REG, Johnson A. 1974. Birmingham University Radiocarbon Dates VIII. Radiocarbon. 16(3):285-303.

Shute CH, Cleal CJ. 1987. Palaeobotany in museums. Geol Curator. 4(9):533-559.

Sibrant ALR, Hildenbrand A, Marques FO, Weiss B, Boulesteix T, Hübscher C, Lüdmann T, Costa ACG, Catalão JC. 2015. Morpho-structural evolution of a volcanic island developed inside an active oceanic rift: S. Miguel Island (Terceira Rift, Azores). J Volcanol Geotherm Res. 301:90-106.

Silva L, Corvelo R, Moura M, Coello RM, Carvalho JA. 2008. Pittosporum undulatum Vent. In: Silva L, Ojeda-Land E, Rodríguez-Luengo JL, editors. Invasive Terrestrial Flora and Fauna of Macaronesia: TOP 100 in Azores, Madeira and Canaries. Ponta Delgada: ARENA; p. 225-228.

Taylor RE. 2016. Radiocarbon dating: development of a nobel method. In: Schuur EAG, Druffel E, Trumbore SE, editors. Radiocarbon and climate change: mechanisms, applications and laboratory techniques. Cham: Springer International Publishing; p. 21-44.

Teixeira C, Pais J. 1976. Introdução à Paleobotânica: As grandes fases da evolução dos vegetais. Lisboa: Escolar Editora.
Traverse A. 2007. Paleopalynology. 2 ed. Topics in geobiology, Vol. 28. Netherlands: Springer.

Trelease W. 1897. Botanical Observations on the Azores. Eighth Annual Report of The Missouri Botanical Garden.

Triantis KA, Borges PAV, Ladle RJ, Hortal J, Cardoso P, Gaspar C, Dinis F, Mendonça E, Silveira LMA, Gabriel R, et al. 2010. Extinction debt on oceanic islands. Ecography. 33:285-294.

Triantis KA, Hortal J, Amorim I, Cardoso P, Santos AMC, Gabriel R, Borges PAV. 2012. Resolving the Azorean knot: a response to Carine and Schaefer (2010). J Biogeograp. 39(6):1179-1184.

Triantis K, Whittaker RJ, Fernández-Palacios JM, Geist DJ. 2016. Oceanic archipelagos: a perspective on the geodynamics and biogeography of the World's smallest biotic provinces. Frontiers of Biogeography. 8(2):e29605.

Walker WF. 1886. The Azores. London: Trubner and Co., Ludgate Hill.

Wallenstein N. 1999. Estudo da História Eruptiva Recente e do Comportamento Eruptivo do Vulcão do Fogo (S. Miguel, Açores) Avaliação Preliminar do Hazard [Unpublished $\mathrm{PhD}$ thesis]. Açores: Universidade dos Açores.

Webster JW. 1821. A Description of the Island of St. Michael, comprising an account of its Geological Structure. Boston, R. P. and C. Williams.

Whittaker RJ, Fernández-Palacios JM. 2007. Island biogeography: ecology, evolution and conservation. New York (NY): Oxford University Press.

Whittaker RJ, Triantis KA, Ladle RJ. 2008. A general dynamic theory of oceanic island biogeography. J Biogeograp. 35(6):977-994.

Zbyszewski G, Moitinho d'Almeida F, da Veiga Ferreira O, Torre de Assunção C. 1958. Carta geológica de Portugal na escala de 1/50 000: Notícia explicativa da folha "B": São Miguel (Açores). Lisboa: Serviços Geológicos de Portugal.

Zbyszewski G, da Veiga Ferreira O, Torre de Assunção C. 1959. Carta geológica de Portugal na escala de 1/50 000: Notícia explicativa da folha "A": São Miguel (Açores). Lisboa: Serviços Geológicos de Portugal.

Zbyszewski G, Moitinho d'Almeida F, da Veiga Ferreira O, Torre de Assunção C. 1959. Carta geológica de Portugal na escala de 1/50 000: Notícia explicativa da folha: Faial (Açores). Lisboa: Serviços Geológicos de Portugal.

Zbyszewski G, Ribeiro Ferreira C, da Veiga Ferreira O, Torre de Assunção C. 1963. Carta geológica de Portugal na escala de 1/50 000: Notícia explicativa da folha "A" da ilha do Pico (Açores). Lisboa: Serviços Geológicos de Portugal.

Zbyszewski G, Cândido de Medeiros A, da Veiga Ferreira O, Torre de Assunção C. 1971. Carta geológica de Portugal na escala de 1/50 000: Notícia explicativa da folha Ilha Terceira. Lisboa: Serviços Geológicos de Portugal. 